\title{
Origin of the Moroccan Touissit-Bou Beker and Jbel Bou Dahar Supergene Non-Sulfide Biomineralization and Its Relevance to Microbiological Activity, Late Miocene Uplift and Climate Changes
}

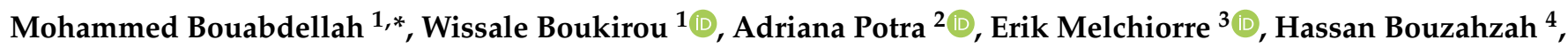 \\ Johan Yans ${ }^{5}$, Khadra Zaid ${ }^{1}$, Mohammed Idbaroud ${ }^{1}$, Julien Poot ${ }^{5}{ }^{\circledR}$, Augustin Dekoninck ${ }^{5}$ \\ and Gilles Levresse ${ }^{6}(\mathbb{D}$
}

check for updates

Citation: Bouabdellah, M.;

Boukirou, W.; Potra, A.; Melchiorre,

E.; Bouzahzah, H.; Yans, J.; Zaid, K.; Idbaroud, M.; Poot, J.; Dekoninck, A.; et al. Origin of the Moroccan Touissit-Bou Beker and Jbel Bou Dahar Supergene Non-Sulfide Biomineralization and Its Relevance to Microbiological Activity, Late Miocene Uplift and Climate Changes. Minerals 2021, 11, 401. https:// doi.org/10.3390/min11040401

Academic Editor: Scott Dunbar

Received: 19 March 2021

Accepted: 9 April 2021

Published: 11 April 2021

Publisher's Note: MDPI stays neutral with regard to jurisdictional claims in published maps and institutional affiliations.

Copyright: (c) 2021 by the authors. Licensee MDPI, Basel, Switzerland. This article is an open access article distributed under the terms and conditions of the Creative Commons Attribution (CC BY) license (https:// creativecommons.org/licenses/by/ $4.0 /)$.
1 Laboratoire des Gîtes Minéraux, Hydrogéologie \& Environnement, Faculté des Sciences, University Mohammed I, Oujda 60000, Morocco; wissale.boukirou@gmail.com (W.B.); zaid.khdra@gmail.com (K.Z.); idbaroud@gmail.com (M.I.)

2 Department of Geosciences, University of Arkansas, Fayetteville, AR 72701, USA; potra@uark.edu

3 Geology Department, California State University, San Bernardino, CA 92405, USA; emelch@csusb.edu

4 Minerals Engineering, Materials and Environment Department, University of Liège, 4000 Liège, Belgium; Hassan.Bouzahzah@uliege.be

5 Institute of Life-Earth-Environment (ILEE), University of Namur, 5000 Namur, Belgium; johan.yans@unamur.be (J.Y.); julien.poot@unamur.be (J.P.); augustin.dekoninck@unamur.be (A.D.)

6 Programa de Geofluidos, Centro de Geociencias UNAM-Campus Juriquilla, Querétaro 76230, Mexico; glevresse@gmail.com

* Correspondence: mbouabdellah2002@yahoo.fr

Abstract: Through integration of $\mathrm{Pb}-\mathrm{Zn} \pm \mathrm{Cu}$ non-sulfide mineralogy, texture, and stable isotope $(\mathrm{C}, \mathrm{O}, \mathrm{S})$ geochemistry, the world-class Touissit- Bou Beker and Jbel Bou Dahar Mississippi Valleytype districts of the Moroccan Atlasic system have been investigated in order to gain insights into the origin and processes that contributed to the formation of the base metal non-sulfide mineralization. In both districts, direct replacement ("red calamine") and wallrock replacement ("white calamine") ores are observed. Based on the mineral assemblages, ore textures, and crosscutting relations, three distinct mineralizing stages are recognized. The earliest, pre-non-sulfide gossanous stage was a prerequisite for the following supergene stages and constituted the driving force that ultimately promoted the leaching of most base metals such as $\mathrm{Zn}$ and $\mathrm{Cu}$ and alkalis from their rock sources. The following two stages, referred to as the main supergene "red calamine" and late "white calamine" ore stages, generated the bulk of mineable "calamine" ores in the Touissit-Bou Beker and Jbel Bou Dahar districts. Stable isotope compositions $\left(\delta^{13} \mathrm{C}_{\mathrm{V}-\mathrm{PDB}}, \delta^{18} \mathrm{O}_{\mathrm{V}-\mathrm{SMOW}}, \delta^{34} \mathrm{~S}_{\mathrm{CDT}}\right)$ support a three-stage model whereby metals were released by supergene acidic fluids and then precipitated by bacteria and archaea-mediated metal-rich meteoric fluids due to a decrease in temperature and/or increase of $f_{\mathrm{O} 2}$. Oxygen isotope thermometry indicates decreasing precipitation temperatures with advancing paragenetic sequence from $33^{\circ}$ to $18^{\circ} \mathrm{C}$, with wet to semi-arid to arid climatic conditions. The close spatial relationships between coexisting sulfide and non-sulfide mineralization along with stable isotope constraints suggest that the oxidation of sulfides occurred concurrently after the main stage of the Alpine orogeny between $15 \mathrm{Ma}$ and the present. More importantly, the current data show for the first time the involvement of biologically controlled activity as the major driving process that triggered both oxidation and deposition of supergene mineralization at Jbel Bou Dahar and Touissit-Bou Beker districts. Conclusions drawn from this study therefore have implications for supergene Mississippi Valley-type (MVT) -derived non-sulfide deposits worldwide and account for the prominent role of biological processes in the genesis of this category of ore deposits.

Keywords: supergene environment; calamine ores; biomineralization; C; O; S isotope geochemistry; High Atlas Morocco 


\section{Introduction}

Long ignored by the mining industry owing to problems with the mineral processing and recovery of the ore, supergene non-sulfide $\mathrm{Zn}-\mathrm{Pb} \pm \mathrm{Cu}$ deposits, formed from low-temperature alteration of exhumed sulfide-bearing protore, are becoming attractive exploration targets worldwide due to the new developments in hydrometallurgy [1-3]. In addition to these advances, the renewed interest in supergene non-sulfide ore at the expense of conventional $\mathrm{Zn}-\mathrm{Pb} \pm \mathrm{Cu}$ deposits resides in their higher $\mathrm{Zn}-\mathrm{Pb} \pm \mathrm{Cu}$ grades averaging up to $20 \mathrm{wt} . \% \mathrm{Zn} \mathrm{[4]} \mathrm{and} 18.1 \mathrm{wt} . \% \mathrm{~Pb}$ [5] and less environmental impact than sulfide ore (e.g., no sulfur emissions or waste, little to no acid mine drainage). Equally important, $\mathrm{Zn}$ non-sulfide ore can greatly improve the smelting of sulfide-rich $\mathrm{Zn}$ and $\mathrm{Pb}$ ore. In addition to base metals, supergene non-sulfide deposits are considered as a potential resource for strategic metals such as $\mathrm{Ge}, \mathrm{Ga}$ and In [6-8] and have the potential to become future alternative sources complementary to alkaline rocks and associated carbonatites. The high demand for these critical metals, which are also recovered as a by-product from non-sulfide $\mathrm{Zn}-\mathrm{Pb} \pm \mathrm{Cu}$ deposits, has spawned worldwide exploration projects focusing on this new, emerging class of supergene ore deposits. Notable examples include Cristal $\mathrm{Zn}$ prospect of Bongará district in northern Peru, Kabwe $\mathrm{Zn}-\mathrm{Pb}$ deposit (formerly known as "Broken Hill") in central Zambia, Tsumeb in Namibia, and Apex deposit in the United States ([6,8-10] and references therein).

Since non-sulfide minerals are recovered through different hydrometallurgical processes such as pyrometallurgy, electrowinning, AmmLeach ${ }^{\circledR}$, and acid leaching ([3] and references therein), the economic value of $\mathrm{Zn}-\mathrm{Pb} \pm \mathrm{Cu}$ non-sulfide ores is dependent not only on the geologic setting of each deposit but also on the initial mineralogy, including the nature of the gangue minerals, the composition and flow rates of groundwater, and the permeability of the ores and host carbonates ([11-13] and the present study). The current understanding of the geological setting, mineralogy, geochemistry, and climatic evolution of the supergene non-sulfide deposits indicates that these deposits formed in a near-surface environment by low-temperature oxidation of a sulfide-rich protolith. The ore-forming process involved a series of reactions between downward-percolating meteoric waters, metal solubility, and reactive host rocks contemporaneously with tectonic uplift and/or water table depression $[3,14,15]$. The released metals could be trapped locally, directly above the sulfide protolith, or they may be transported and precipitated far away from the sulfide protore [3,16-19]. More importantly, recent investigations demonstrated the ability of bacteria and archaea as well to influence metal solubilization, mobilization, and subsequent formation of carbonate-hosted $\mathrm{Pb}-\mathrm{Zn} \pm \mathrm{Cu} \pm \mathrm{Au}$ deposits and their supergene counterparts (e.g., [20-25]).

The Tethyan intra-continental Atlas system of Northwest Africa [26] hosts more than 1000 sulfide $\mathrm{Pb}-\mathrm{Zn} \pm \mathrm{Cu} \pm \mathrm{F} \pm \mathrm{Ba}$ orebodies and deposits that range from small uneconomic showings to major districts of great size and productivity (Figure 1). Major and most productive deposits occur in Morocco within unmetamorphosed, flat-lying Lower and Middle Jurassic carbonates that experienced multiple overlapping episodes of dolomitization, dissolution (i.e., karstification), and uplift during the Mesozoic breakup of the Pangean continental shelf of Northwest Africa. Featured deposits and districts, which are introduced in this contribution, include the word-class and historically important Touissit-Bou Beker (>100 Mt at 4 wt.\% Pb, 3.5 wt.\% Zn, <1 wt.\% Cu, 120 g/t Ag; [5]) and the Jbel Bou Dahar (>30 Mt at $4 \mathrm{wt} . \% \mathrm{~Pb}, 4 \mathrm{wt} . \% \mathrm{Zn}$ ) districts (Figure 1). Both sulfide and non-sulfide mineralization coexist in these two major districts, with the supergene $\mathrm{Pb}-\mathrm{Zn} \pm \mathrm{Cu}$-bearing occurrences being superimposed on the surviving oxidized sulfide protore. Earlier studies indicate that the primary sulfide mineralization is of Mississippi Valley-type (MVT) affiliation [5,26-28]. Major advances in understanding the genesis of MVT mineralization have been accomplished over the last two decades, principally as a result of field observations, mineralogical assemblages, and textural characterization, along with fluid inclusions and stable and radiogenic isotope geochemistry [5,26-29]. 
However, the mineralogy and origin of the non-sulfide ores have been neglected and have only recently become the subject of ongoing investigations [30-32].

In this contribution, we report the first comprehensive carbon, oxygen, and sulfur isotope dataset from the abovementioned two representative and the largest MVT districts of the Moroccan Atlas system (Figure 1). Although the selected districts share many similarities in terms of their geological environments and age of mineralization, they show, however, contrasting $\mathrm{Zn} / \mathrm{Pb}$ ratios that make them distinct from each other (i.e., $\mathrm{Pb}$-dominant vs. Zn-dominant deposits), providing an ideal methodological approach to investigate the role of initial sulfide mineralogy in controlling the distribution of the supergene non-sulfide ore. The aim was to fill the gap of knowledge on non-sulfide $\mathrm{Pb}-\mathrm{Zn} \pm$ $\mathrm{Cu}$ deposits and to better constrain the nature of the fluids involved in the mineralizing process within the framework of geodynamics and paleoclimatic evolution of the Atlas, assess the role of microbial processes in their formation, a topic that has started to attract the interest of economic geologists only recently, and draw a distinction between "white" and "red" calamine ores. The specific objectives were fourfold: (1) update the geologic attributes, petrography, mineralogy, and geochemistry of the non-sulfide $\mathrm{Pb}-\mathrm{Zn} \pm \mathrm{Cu}$ orebodies; (2) refine the paragenetic relationship between sulfides, non-sulfides, and their associated gangue minerals; (3) discuss the close temporal links between non-sulfide ore formation, tectonic uplift, regional climatic evolution, and biogenic processes; and (4) combine the newly acquired isotopic results with published isotopic data from other non-sulfide deposits around the world to constrain the genesis of supergene mineralization.

In this study, we provide macrotextural and carbon and sulfur isotope evidence supporting the hypothesis that the microorganisms played a major role in the formation of the major Moroccan non-sulfide $\mathrm{Pb}-\mathrm{Zn} \pm \mathrm{Cu}$ deposits in the Atlasic system. This will thus contribute to the identification of new targets throughout this vast metallogenic province, which contains some of the best prospects for undiscovered non-sulfide $\mathrm{Pb}-\mathrm{Zn} \pm \mathrm{Cu}$ deposits.

\subsection{Regional Geological Setting and Mineralization}

The regional geologic setting of the two investigated districts has been the subject of several pioneering studies $[5,26,28,33-36]$. A summary of these results is presented here, with an emphasis on the Mesozoic to Cenozoic stratigraphic and tectonic events that the MVT mineralization and the superimposed non-sulfide $\mathrm{Pb}-\mathrm{Zn} \pm \mathrm{Cu}$ ores are related to. 


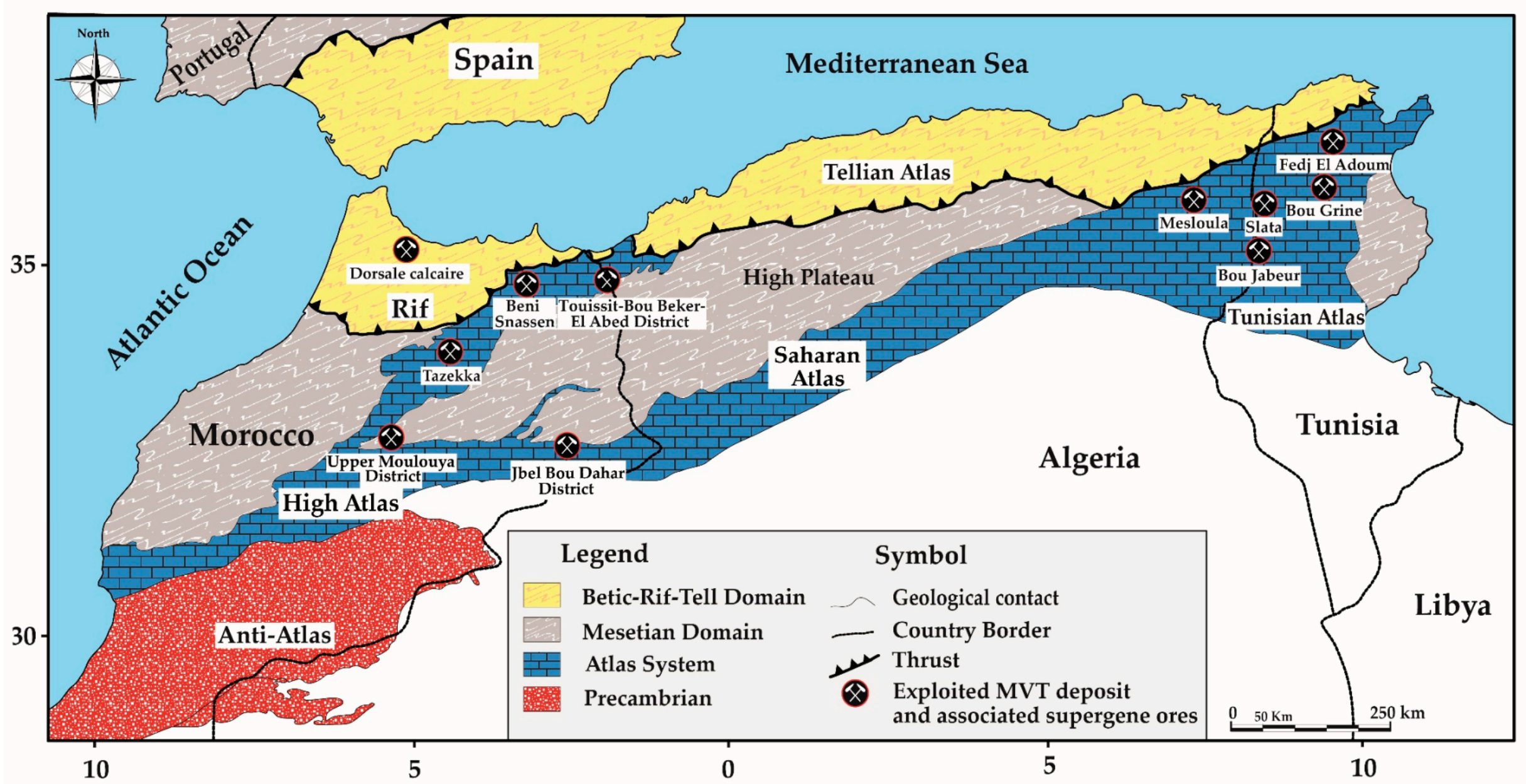

Figure 1. Geologic map of northwestern Africa and southern Iberia illustrating the main lithostructural domains and spatial distribution of major Maghrebian (i.e., Moroccan, Algerian, and Tunisian) Mississippi Valley-type (MVT) districts within the Atlas system (adapted from [26]). 
Overall, the Mesozoic and Cenozoic stratigraphy of the Atlas system, to which all of the investigated districts belong, consists of a succession of rift-related Triassic-Early Jurassic red-bed formations and intercalated carbonate rocks. These lithologies are overlain by a series of post-rift sub-horizontal and unmetamorphosed Middle-Late Jurassic to Early Cretaceous carbonate and marl strata that were deposited into a succession of alternating horst and graben structures related to the opening of the Tethyan and Atlantic oceans $[37,38]$. The sedimentary succession was folded and thrusted in response to the Late Cretaceous-Cenozoic Atlasic orogeny, which developed in response to the convergence between the African and Eurasian plates. The regional stress regime inverted from extensional to compressional tectonics since the Late Cretaceous, with the fault network inherited from the rifting episodes playing a first-order control on the inversion [39-44]. Lower to Middle Jurassic carbonate strata are exceptionally well endowed in $\mathrm{Pb}-\mathrm{Zn} \pm$ $\mathrm{Cu}$ deposits of MVT affiliation [26], some of which are of world-class significance. In all cases, mineralization is epigenetic (i.e., ore genesis postdates deposition and diagenetic lithification of carbonate host rocks) and occurs either as replacement of the carbonate host rock or as open-space filling of karsts, veins, vugs, and brecciated fault zones. Recent contributions have established close temporal links between supergene ore formation and regional geotectonic and paleoclimatic evolution $[26,30]$.

\subsection{Touissit-Bou Beker District Geology}

The Touissit-Bou Beker district of northeastern Morocco and adjacent western Algeria (Figures 1 and 2A) is one of the top ten MVT districts in the world, with a total production, over 75 years of mining activity, that exceeded $5 \mathrm{Mt}$ of $\mathrm{Pb}$ and $\mathrm{Zn}[5,28]$.

The district stratigraphy consists of a Paleozoic basement unconformably overlain by a series of tabular and unmetamorphosed Meso-Cenozoic to Quaternary terranes (Figure 2B). The Aalenian-Bajocian (Middle Jurassic) dolomitic sequence, which hosts nearly all economic deposits of the Touissit-Bou Beker district, rests either directly on the Paleozoic basement or conformably overlies the Early Jurassic unit. The mineralogy of the deposits is very simple, comprising sphalerite and galena, with minor pyrite-marcasite and sparse chalcopyrite \pm sulfosalts (i.e., tetrahedrite), accompanied by different generations of hydrothermal dolomite. Supergene mineral assemblages are extensively developed, with the oxidized ore zones extending as deep as $120 \mathrm{~m}$ and accounting for nearly $60 \%$ of the extracted ore [5]. The geometry of the orebodies that parallel the Atlasic ENE-WSWand $\mathrm{E}-\mathrm{W}$-trending faults [45-47] coupled with $\mathrm{Pb}-\mathrm{Pb}$ geochronological data [5] suggest that the MVT mineralizing event occurred during the Late Miocene at $<15$ Ma $[5,26,28]$, consistent with the time span determined for most of the north African MVTs [29,48]. 

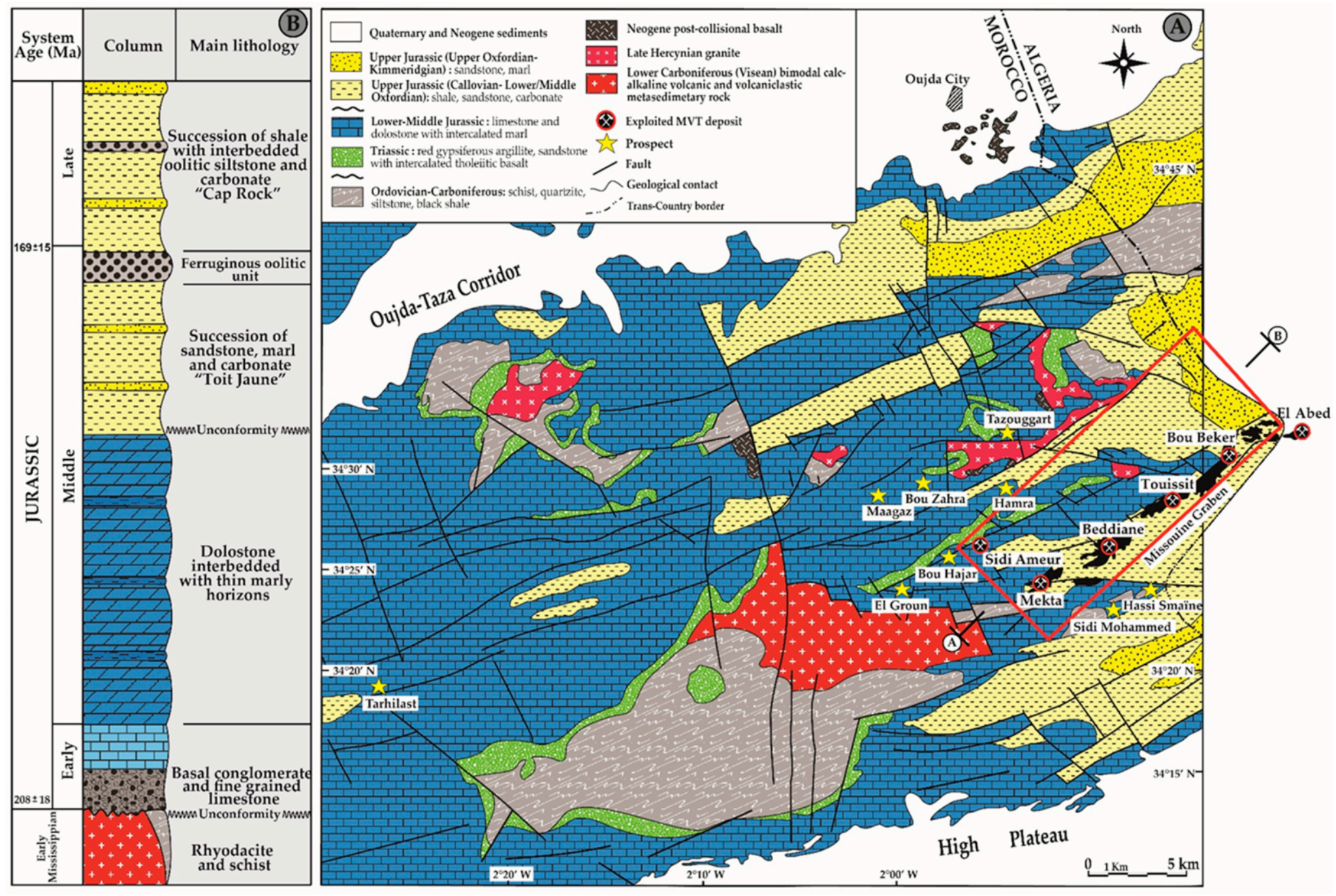

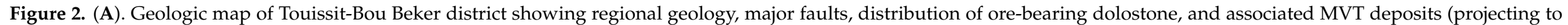

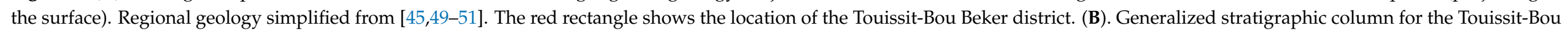
Beker district showing main lithostratigraphic units. 


\subsection{Jbel Bou Dahar District Geology \\ 1.3.1. Mining History}

Production of lead, zinc, and barite in the Jbel Bou Dahar district and the surrounding areas is carried out exclusively through artisanal mining under the auspices of the CADETAF "Purchasing and Development Cooperative for the Tafilalet and Figuig Mining Region", a public institution created following the Royal Decree of December 1st, 1960. The CADETAF claims, covering an area that extends over $60,000 \mathrm{~km}^{2}$ in the central and eastern High Atlas, together with the mineral exploration licenses currently owned by the mining company ManagemGroup, define the largest and most productive "calamine" province in North Africa. Compiled data provided by both the CADETAF and ManagemGroup indicate that $>1 \mathrm{Mt}$ of $\mathrm{Zn}$ ore, with a grade exceeding $30 \% \mathrm{ZnO}$, has been produced to date. For instance, from 2012 to 2019, ManagemGroup produced a total of 559,403 tons grading $\sim 16 \% \mathrm{Zn}$.

\subsubsection{Geologic Setting}

The Jbel Bou Dahar plateau occurs as an elongated, ENE-trending, 35 to $40 \mathrm{~km}$ long and 4 to $15 \mathrm{~km}$ wide flat-topped mountain with all of the current and past mine workings being distributed along the margins of the Lower Jurassic carbonate platform (Figure 3). The core of the carbonate platform consists of a succession of greenschist-facies CambrianOrdovician to Silurian metasedimentary and volcaniclastic rocks made up dominantly of quartzite and schist. Unconformably overlying the metasedimentary Paleozoic package is a sequence of about 400-500 m thickness of Triassic sedimentary rocks consisting of red-bed siltstone and gypsiferous to salt-bearing argillite locally interbedded with CAMP tholeiitic basalts [52]. The reef deposits consist of unmetamorphosed, flat-lying, massive, thickly bedded coral-, algal-, and bivalve-bearing Pliensbachian platform carbonates. Platform growth was initiated during the Sinemurian and ended during the Domerian (Upper Pliensbachian)-Middle Toarcian [53-56]. The Jurassic to Cretaceous strata were dissected by an array of faults, some larger and more continuous, trending mainly $\mathrm{E}-\mathrm{W}$, with some trending ENE-WSW and a subsidiary set trending NNW-SSE (Figure 3). Sulfide $\mathrm{Pb}$ $\mathrm{Zn}-\mathrm{Ba} \pm \mathrm{Cu}$ orebodies are confined to the brecciated, coarse sand to gravel, bioclastic bivalve-coral-algal packstones of Pliensbachian age, and/or to pinchouts of the Liassic strata against Paleozoic basement high (Figure 4). The sulfide mineralogy is fairly simple and consists of variable amounts of sphalerite, galena, pyrite-marcasite, and chalcopyrite, accompanied by barite, celestite, and calcite as the main gangue minerals. 


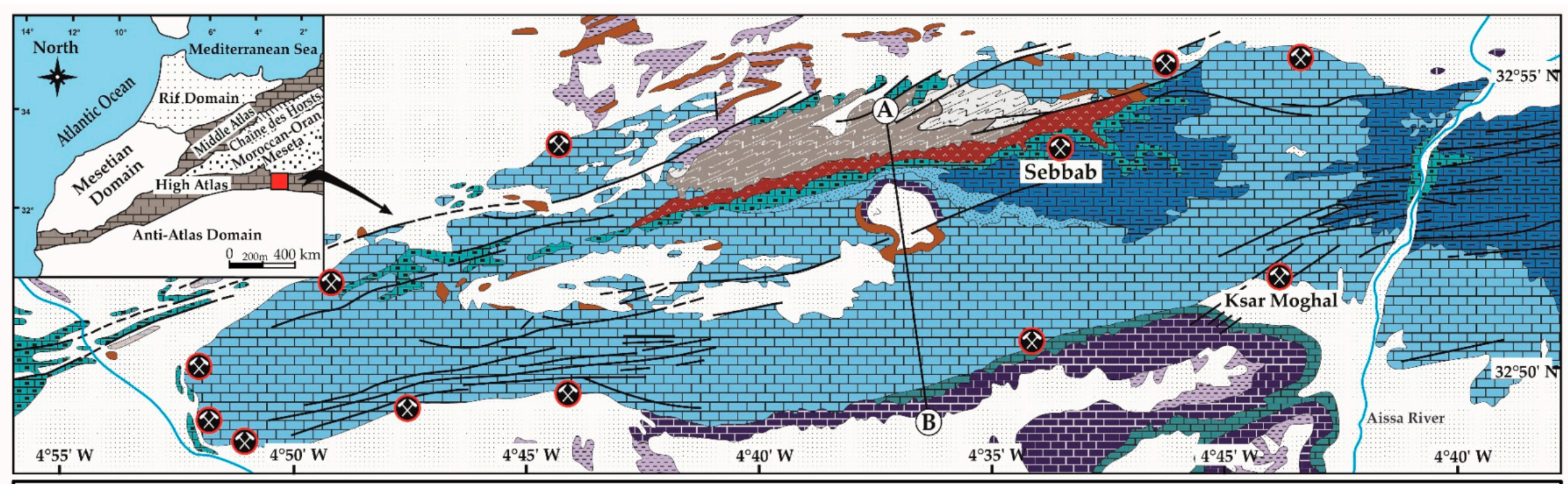

\section{Legend}

Quaternary: alluvions and colluvions

$\sim$ Uncomformity

Lower-Middle Bajocian: Bositra buchi RÖMER

=Posidonia alpina Gras, P. ornati Quenstedt,) marl Formation

Aalenian-Bajocian: transgressive red limestones with intercalated iron-bearing oolites

Aalenian: Concellophycus-bearing limestones

Toarcian-Aalenian: neptunian dike filled with fossiliferous reddish carbonates

Domerian-Lower Toarcian: condensed succession of

ammonite-brachiopod-bearing reddish carbonates

质眾 Upper Sinemurian-Domerian: open-marine basinal carbonates and marls

Upper Sinemurian-Domerian: shallow to deep sub-marine plateform carbonates

Lotharingian: grey, massive to oolitic carbonates with intercalation of red marls

I:-. Sinemurian: supra- to intertidal bedded reefal carbonates

Sinemurian: supra- to intertidal bedded resto
(limestones and stromatolitic dolostones)

Triassic: red bed basal conglomerates and sandstones with gypsum-and salt-bearing argillites locally interdedded with tholeiitic basalts Uncomformity

Silurian: dark-grey quartzites and Graptolith-bearing schistose pelites Ordovician: Schistose pelites, Scolithus-bearing quartites, sandstones, and microconglomerates

\section{Symbol}

Fault

$\sim$ Geological contact

$\sim r$ Hard-ground

Exploited MVT deposit

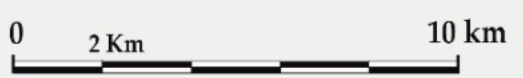

$2 \mathrm{Km}$

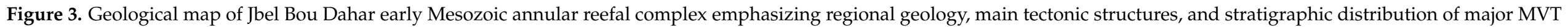
deposits. Line A-B indicates cross section shown in Figure 4. Modified after [57]. 


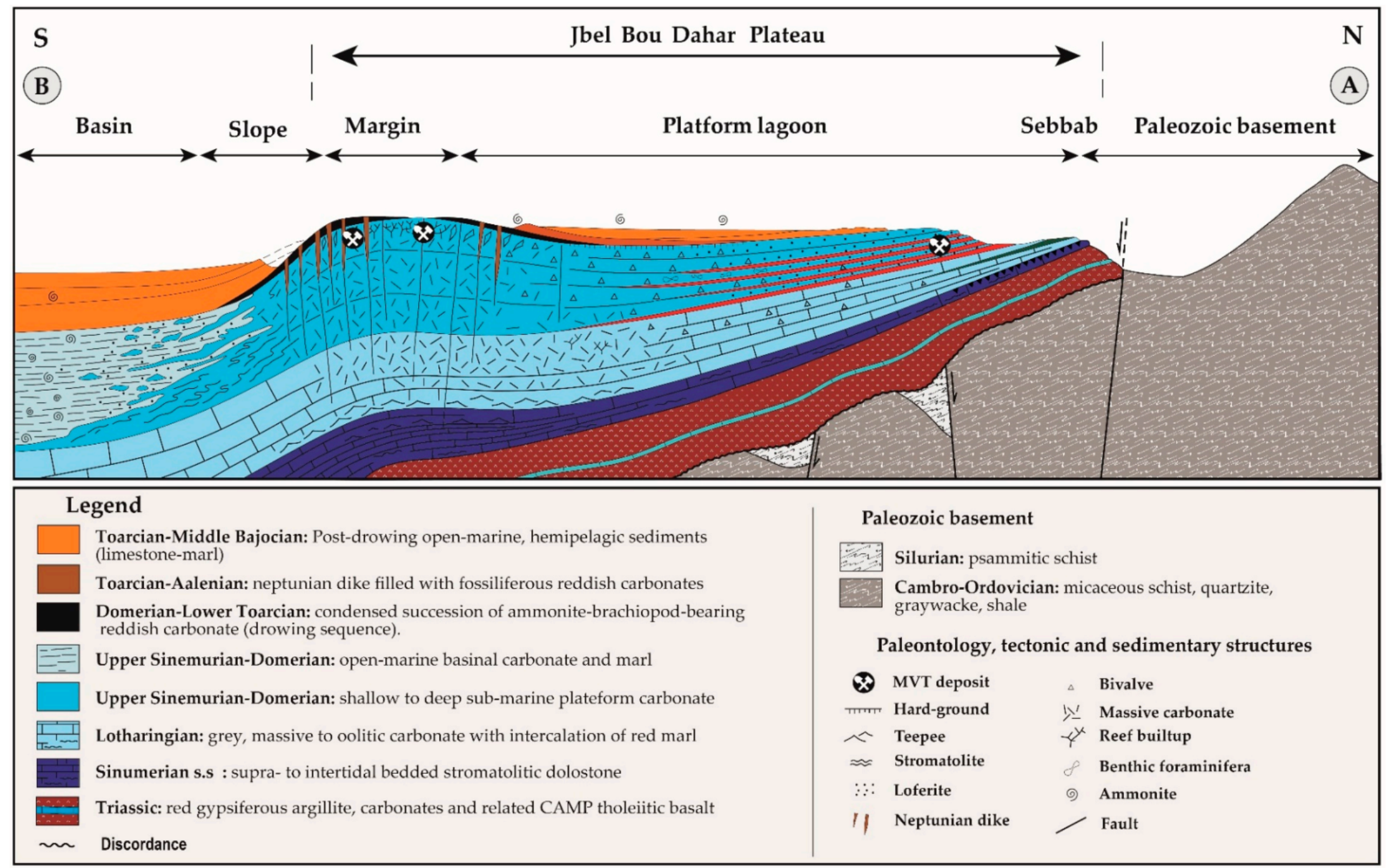

Figure 4. N-S geological section along strike of Jbel Bou Dahar early Mesozoic carbonate platform showing the spatial distribution of main lithofacies associations and MVT deposits; see Figure 3 for location of section. Modified after [57]. 


\section{Materials and Methods}

The sample suite analyzed in this contribution for mineralogical and geochemical studies includes a total 59 mineral separates collected from surface outcrops, high-grade open pits, and underground workings to obtain a representative suite of the principal minerals deposited throughout the two main supergene stages recognized throughout the Touissit-Bou Beker and Jbel Bou Dahar districts. In all cases, and in order to avoid analysis of impurities, $\mathrm{Pb}-\mathrm{Zn} \pm \mathrm{Cu}$-bearing carbonates and gypsum separates were extracted from crushed and washed fractions. Only pure separates of each mineral phase were analyzed.

The selected samples were mounted on Epoxy resin for polished block preparation to perform microscopic observations. The entire surface of each polished block was imaged by an optical microscope (Zeiss AxioImager M2m, Carl Zeiss AG, Oberkochen, Germany) with an XYZ motorized stage to obtain tiled images that allowed the sample to be navigated under the Scanning Electron Microscope (SEM) with micrometric precision owing to correlative microscopy. Detailed mineral stoichiometry was addressed using a Zeiss (Sigma 300) field emission gun SEM equipped with two Bruker xFlash 6/30 Xray energy-dispersive spectrometers (EDS) at the laboratory of Minerals Engineering, Materials and Environment (GeMMe) of University of Liège (Belgium). The SEM-EDS analyses were carried out using a probe current of $2.3 \mathrm{nA}$ with an accelerating voltage of $20 \mathrm{kV}$ at a working distance of $8.5 \mathrm{~mm}$. Manual spot analysis was performed to identify the carbonate $\mathrm{Pb}-\mathrm{Zn} \pm \mathrm{Cu}$-bearing minerals and surrounding phases using backscattered electron (BSE) and cathodoluminescence (CL) imaging modes. Additional samples were observed on a Zeiss Axiophot reflection microscope equipped with a Jeol JSM-7500F SEM coupled to an EDS, and with a Zeiss Sigma 300 FEG SEM (Carl Zeiss AG, Oberkochen, Germany) equipped with two Bruker EDS detectors (Bruker Corporation, Massachusetts, USA) at the University of Namur (Belgium).

Carbon and oxygen isotope analyses were carried out at the Radiometric Dating and Stable Isotope Research laboratory at the University of Erlangen-Nuremberg (Germany) and California State University on hand-picked carbonate minerals including cerussite, smithsonite, malachite, azurite, and anglesite as well as on calcite. Carbonate powders were reacted with $100 \%$ phosphoric acid at $70{ }^{\circ} \mathrm{C}$ using a Gasbench II connected to a ThermoFisher Delta V Plus mass spectrometer. Reproducibility and accuracy were monitored by replicate analysis of laboratory standards calibrated by assigning a $\delta^{13} \mathrm{C}$ of $+1.95 \%$ to NBS19 and $47.3 \%$ to IAEACO 9 and a $\delta^{18} \mathrm{O}$ of $2.20 \%$ to NBS19 and $23.2 \%$ to NBS18. Analytical precision $(1 \sigma)$ was calculated on the basis of multiple measurements of wellcharacterized carbonate standards between sample runs and was better than $0.01 \%$ for $\delta^{13} \mathrm{C}$ and $0.02 \%$ for $\delta^{18} \mathrm{O}$, after corrections for scale compression.

Isotopic data are reported here relative to the Standard Mean Ocean Water (V-SMOW) for oxygen and to the PeeDee Belemnite (V-PDB) for carbon [58]. Oxygen isotope data have been converted into temperature estimates using the isotope thermometer of [59] for cerussite, [60] for smithsonite, [61] for malachite, [62] for azurite, and [63] for calcite. For these calculations, groundwater involved in forming the carbonates was assumed to have an oxygen isotope value of $-7.2 \%$. This value is based on both modern groundwater and fluid inclusion values, consistent with those reported in [62]. Reproducibility was checked by replicate analysis of laboratory standards and was better than $\pm 0.07 \%$ o $(1 \sigma)$ for both carbon and oxygen isotope analyses.

Isotope geothermometry was used in conjunction with the results of oxygen isotope analyses for the $\mathrm{Pb}-\mathrm{Zn} \pm \mathrm{Cu}$-bearing carbonates to produce estimates of the temperatures at which these divalent metal cation carbonates formed. In this respect, it must be noted that these are thermometry estimates, as they represent an estimation of the thermal conditions under which the minerals are likely to have formed. Critical to the accuracy of this technique is an understanding of the oxygen isotope value of the waters from which these minerals formed. It has been shown by many studies that modern meteoric water values often serve as a good proxy for the waters of formation, due to the relatively recent 
formation of secondary carbonates $[9,61,62,64,65]$. Furthermore, the use of the hydrogen isotope values of water extracted from fluid inclusions may be used to extract a proxy for oxygen isotope values for the water of formation, using the meteoric water relationship [65]. However, the large quantity of pure mineral required for such analysis on a crushing stage precludes multiple analyses. It is also known that clay hydrogen isotope values may be used as a proxy for meteoric waters from as far back as tertiary weathering environments, with attendant implications for the waters of formation of metal carbonate minerals (e.g., [64,65]). As with other studies $[9,61,62,64,65]$, it is assumed that there may be as much as $1 \%$ variation in oxygen isotope values using these methods, based upon known issues such as seasonal variability in precipitation sourcing. Such a variation would yield a maximum thermometry error of less than $6^{\circ} \mathrm{C}$; far less than the range of variation seen in the samples from this present study.

The sulfur isotope compositions were determined at Actlabs (Canada) using the online elemental analyzer (Carlo Erba 1108) continuous flow-isotope ratio mass spectrometer (Finnigan Mat Delta S). Data are reported as per mil (\%) deviations relative to the Canyon Diablo troilite (CDT) standard. Analytical uncertainty $(2 \sigma)$ was $\pm 0.2 \%$. The experimental procedure involved the liberation of $\mathrm{SO}_{2}$ gas by rapid combustion of the samples with vanadium pentoxide. In total, 16 mineral separates, including 11 sulfates (gypsum) and 5 sulfides (late-stage pyrite) were analyzed for sulfur isotope ratios (Table 1). Finally, it should be noticed that while carbon and sulfur cycling are usually associated in the oxidation zone, they are fundamentally independent cycles.

Table 1. Representative carbon, oxygen, and sulfur isotope compositions, expressed as \%o $\delta^{18} \mathrm{O}_{\mathrm{V}-\mathrm{SMOW}}, \delta^{13} \mathrm{C}_{\mathrm{V}-\mathrm{PDB}}$ and $\delta^{34} \mathrm{~S}_{\mathrm{CDT}}$, respectively for supergene carbonate (cerussite, smithsonite, calcite) and sulfate (gypsum) minerals along with late-stage pyrite from various mineralizing stages from the Touissit-Bou Beker (TB) and Jbel Bou Dahar (JBD) districts.

\begin{tabular}{|c|c|c|c|c|c|c|}
\hline Sample ID & Mineral & Brief Description/Paragenesis & $\delta^{13} \mathrm{C}_{\mathrm{V}-\mathrm{PDB}}$ & $\delta^{18} \mathrm{O}_{\mathrm{V} \text {-SMOW }}$ & $\delta^{34} S$ & $\mathrm{~T}\left({ }^{\circ} \mathrm{C}\right)$ \\
\hline TB1 & Cerussite & Transparent cerussite lining vug (Cer-2) & -12.95 & 12.48 & - & 36 \\
\hline TB2 & Cerussite & Cerussite post saddle dolomite crowing on massive galena (Cer-1) & -15.09 & 12.59 & - & 35 \\
\hline TB3 & Cerussite & Transparent cerussite encrusted on massive galena (Cer-1) & -12.76 & 10.36 & - & 50 \\
\hline TB4.1 & Cerussite & Transparent cerussite encrusted on galena (Cer-1) & -14.21 & 20.23 & - & -4 \\
\hline TB4.2 & Smithsonite & Massive smithsonite from high-grade ore (Sm-1) & -1.44 & 29.37 & - & -2 \\
\hline TB5 & Azurite & Crystalline azurite associated with late fibrous malachite (Az-2) & -7.68 & 26.21 & - & 29 \\
\hline TB6 & Azurite & Crystalline azurite $(\mathrm{Az}-1)$ & -2.77 & 26.80 & - & 26 \\
\hline TB7 & Azurite & Crystalline azurite with subordinate malachite $(\mathrm{Az}-1)$ & -7.40 & 26.17 & - & 30 \\
\hline US-TB8 & Azurite & Azurite & -7.51 & 26.02 & - & 30 \\
\hline US-TB9 & Azurite & Azurite & -7.37 & 26.53 & - & 28 \\
\hline US-TB10 & Azurite & Azurite & -7.72 & 26.21 & - & 29 \\
\hline US-TB11-1 & Azurite & Azurite & -7.73 & 26.19 & - & 30 \\
\hline TB12 & Malachite & Bothroidal malachite (Mal-2) & -4.06 & 25.70 & - & 24 \\
\hline TB13 & Malachite & Bothroidal malachite & -5.19 & 24.85 & - & 25 \\
\hline US-TB11-2 & Malachite & Bothroidal malachite & -4.67 & 25.24 & - & 23 \\
\hline TB15 & Calcite & Late stage calcite calcite encrusted on dolomite & -8.77 & 20.65 & - & 25 \\
\hline TB16 & Calcite & Late-stage rhombohedral calcite & -8.69 & 21.70 & - & 20 \\
\hline TB17 & Calcite & Late-stage rhombohedral calcite & -1.17 & 21.60 & - & 20 \\
\hline TB18 & Calcite & Late-stage rhombohedral calcite & $-3,09$ & 19.20 & - & 32 \\
\hline TB19 & Calcite & Late-stage rhombohedral calcite & -8.51 & 23.30 & - & 13 \\
\hline TB20 & Calcite & Late-stage rhombohedral calcite & -8.51 & 21.80 & - & 19 \\
\hline US-TB11-3 & Calcite & Late-stage euhedral calcite & -2.89 & 22.75 & - & 15 \\
\hline TB22 & Gypsum & Transparent gypsum encrusted on galena (Gyp-1) & - & 0.60 & 6.70 & - \\
\hline TB23 & Gypsum & Fibrous gypsum encrusted on dolostone (Gyp-2) & - & 2.40 & -15.80 & - \\
\hline TB24 & Gypsum & Fibrous gypsum encrusted on dolomite (Gyp-2) & - & 3.70 & -11.30 & - \\
\hline TB25 & Gypsum & Fibrous secondary gypsum (Gyp-2) & - & - & -6.18 & - \\
\hline TB26 & Gypsum & Fibrous secondary gypsum (Gyp-2) & - & - & -7.25 & - \\
\hline TB27 & Gypsum & Fibrous secondary gypsum (Gyp-2) & - & - & -13.46 & - \\
\hline TB28 & Gypsum & Fibrous secondary gypsum (Gyp-2) & - & - & -14.11 & - \\
\hline TB29 & Gypsum & Fibrous secondary gypsum (Gyp-2) & - & - & 2.28 & - \\
\hline TB30 & Pyrite & Euhedral late-stage pyrite encrusted on saddle dolomite & - & - & -12.60 & - \\
\hline TB31 & Pyrite & Euhedral late-stage pyrite encrusted on saddle dolomite & - & - & -16.80 & - \\
\hline TB32 & Pyrite & Euhedral late-stage pyrite encrusted on saddle dolomite & - & - & -16.80 & - \\
\hline TB33 & Pyrite & Euhedral late-stage pyrite encrusted on saddle dolomite & - & - & -16.20 & - \\
\hline TB34 & Pyrite & Euhedral late-stage pyrite encrusted on saddle dolomite & - & - & -16.60 & - \\
\hline JBD1 & Smithsonite & Layered smithsonite (Sm-1) & -6.44 & 24.22 & - & 18 \\
\hline JBD2 & Smithsonite & Bothroidal smithsonite from high-grade ore (Sm-1) & -5.43 & 21.93 & - & 28 \\
\hline JBD3 & Smithsonite & Smithsonite from mixed $\mathrm{Pb}-\mathrm{Zn}$ ore $(\mathrm{Sm}-1)$ & -6.15 & 24.52 & - & 17 \\
\hline JBD4 & Smithsonite & Layered red ore smithsonite $(\mathrm{Sm}-1)$ & -1.31 & 23.61 & _- & 21 \\
\hline JBD5 & Smithsonite & Bothroidal smithsonite (Sm-1) & -5.64 & 25.05 & - & 14 \\
\hline
\end{tabular}


Table 1. Cont.

\begin{tabular}{|c|c|c|c|c|c|c|}
\hline Sample ID & Mineral & Brief Description/Paragenesis & $\delta^{13} C_{\mathrm{V}-\mathrm{PDB}}$ & $\delta^{18} \mathrm{O}_{\mathrm{V}-\mathrm{SMOW}}$ & $\delta^{34} S$ & $\mathrm{~T}\left({ }^{\circ} \mathrm{C}\right)$ \\
\hline JBD6 & Smithsonite & Smithsonite from mixed ore (Sm-2) & -5.01 & 25.70 & - & 12 \\
\hline JBD8 & Smithsonite & Bothroidal Smithsonite (Sm-2) & -4.83 & 25.88 & - & 11 \\
\hline JBD9 & Calcite & Late stage "en dents de cochon" calcite & -3.07 & 18.65 & - & 34 \\
\hline JBD10 & Calcite & Late stage columnar calcite & -8.92 & 21.55 & - & 20 \\
\hline JBD11 & Calcite & Late stage stalactitic calcite encrusted on dolomitized limestone & -7.74 & 24.37 & - & 9 \\
\hline JBD12 & Gypsum & Transparent gypsum associated with sphalerite & - & - & 5.1 & - \\
\hline JBD13 & Gypsum & Transparent gypsum associated with sphalerite & - & - & 9.6 & - \\
\hline JBD14 & Gypsum & Transparent gypsum associated with sphalerite & - & - & 6.1 & - \\
\hline
\end{tabular}

\section{Results}

\subsection{Introduction}

In the two studied districts, partial to complete oxidation of $\mathrm{Zn}-\mathrm{Pb} \pm \mathrm{Cu}$ sulfides occurs at depths ranging from a few meters from the surface down to hundreds of meters below the present water table. It is noteworthy that oxidation of the primary sulfides reveals typical vertical alteration profiles within individual deposits, with the shallow oxides of $\mathrm{Fe}, \mathrm{Mn}$, and $\mathrm{Cu}$ predominating in the upper part of the deposits, grading downward through the mixed non-sulfide and sulfide $\mathrm{Zn}-\mathrm{Pb} \pm \mathrm{Cu}$ mineralization to the unaltered buried sulfide protore. Moreover, the supergene mineralization shows intimate spatial relationships with major faults as most of the enriched orebodies occur in the footwall of, or adjacent to, major faults, thus allowing incursion of meteoric water and oxidation of the primary ore.

\subsection{Mode of Occurrence}

In the Touissit-Bou Beker district, approximately $70 \%$ of the total $\mathrm{Pb}-\mathrm{Zn} \pm \mathrm{Cu}$ production is derived from non-sulfide counterparts, including $\mathrm{Pb}$-carbonates and $\mathrm{Pb}$-sulfates (i.e., "cerussitic" ore, [5]). Some orebodies are oxidized to the extent that the only surviving sulfide is galena (Figure 5A). The most impressive example is represented by the so-called "collapse zone", which hosts some of the higher-grade orebodies of the district, approaching $20 \% \mathrm{~Pb}$. Of these, the clay-hosted Hassi Msidira orebody is the most intriguing one, owing to the clayey, rather than carbonaceous, nature of the host rocks and to the higher grade of the ore, averaging $18 \% \mathrm{~Pb}$. The mineralization consists of massive blocks of galena embedded in a residual reddish-brown to yellow-brown matrix made up of finely to strongly laminated Zn-bearing clays (i.e., illite and kaolinite \pm smectite) (Figure 5B). The clays contain Fe (hydr)oxide pseudomorphs after pyrite as well as non-sulfide $\mathrm{Zn}$ rich carbonate minerals grading locally $4.5 \% \mathrm{Zn}$, of which $1.9 \%$ is represented by $\mathrm{ZnO}$. Within the same horizon, the boundary between the clay-hosted ore zone is unweathered Aalenian-Bajocian gray dolostone consisting of a distinctive reddish, hematitic Zn-bearing "sandy" dolomite and remnants of original dolostone (Figure 5C). 

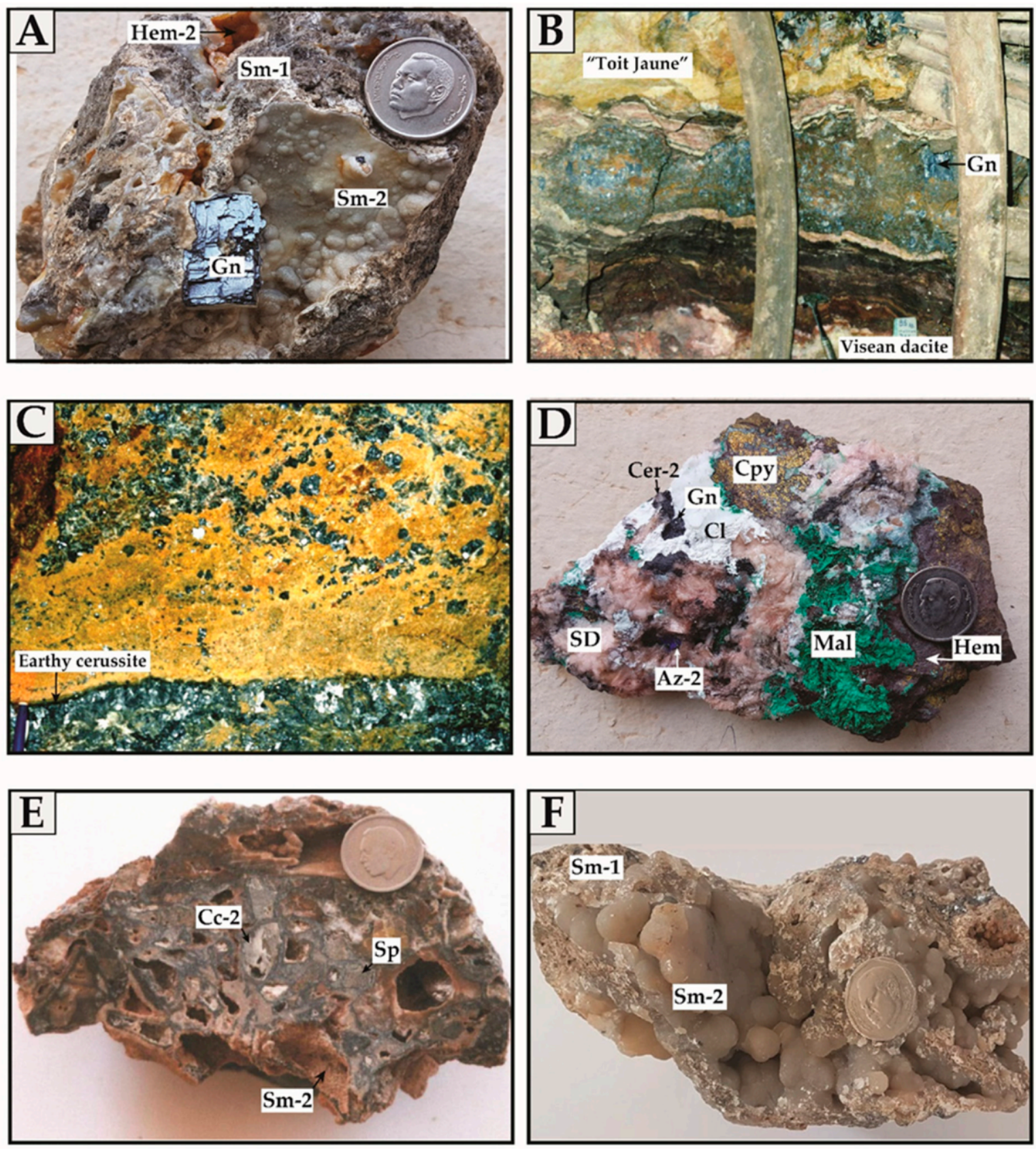

Figure 5. Selected underground exposures and hand samples from the Touissit-Bou Beker and Jbel Bou Dahar district deposits, illustrating representative styles of non-sulfide mineralization and textural variations of different ore types. (A) Surviving cubic galena (Gn) crystal rising up in a matrix of white calamine surrounded by aggregates of botryoidal smithsonite (Sm). (B) Underground exposure at the Hassi Msidira orebody, illustrating an example of clay-hosted galena. Notice that the normally $25 \mathrm{~m}$ thick ore-bearing dolostone (D2) has been completely dissolved, leaving an approximately $2 \mathrm{~m}$ thick layer of insoluble residue made of variously colored, laminated clays, accompanied locally by massive galena clasts (blue dots). TJ = "Toit jaune". (C) Close up of an underground exposure showing a dissolution cavity filled with clastic internal sediments (i.e., speleothems). Note that the galena fragments and dispersed in a silt- to sand-sized iron-rich dolomite referred to as "sandy dolomite" recognizable by its oxidation ochre-yellow color. Note also that the base of the cavity is lined by a fine film of black earthy cerussite "cerussite pierreuse". (D) Hand sample of high-grade copper rich-ore showing brecciated chalcopyrite (Cpy), pyrite and hydrothermal dolomite with malachite (Mal) and hematite (Hem) sealing the fractures. Note the later development of white clays $(\mathrm{Cl})$ and azurite $(\mathrm{Az})$ crystals lining the remaining vugs. (E) Vuggy to cellular sponge texture derived from dissolution-replacement of coarse-grained sphalerite (Sp) and its subsequent filling. The resulting boxwork cavities are characteristically filled by late-stage calcite (CC), concretionary smithsonite and later iron oxides. (F). Close up of a cm-wide dissolution cavity filled with botryoidal smithsonite. 
This gradational contact led the authors of [5] to interpret the collapse zone as internal sediment "trash zone" formed by complete meteoric dissolution of the host carbonate rocks and leaving behind clays (illite and kaolinite \pm smectite), quartz, and organics as insoluble residue, along with oxidized $\mathrm{Pb}-\mathrm{Zn}$ occurrences of $\mathrm{Pb}-\mathrm{Zn}$ carbonates (mainly cerussite and smithsonite) and sulfates (anglesite).

Rich azurite and malachite mineralization occurs in the central part of the Beddiane mine within the upper part of the Aalenian-Bajocian dolomitic strata, close to the Late Bajocian-Lower Bathonian sandstone to carbonate hanging-wall rocks (i.e., "Toit Jaune" ,; [5]). Copper mineralization may also extend into the overlying Callovian-Oxfordian rocks and the "Toit Jaune", itself for $10 \mathrm{~m}$ or more [5]. It is noteworthy that the carbonatedominated copper zone is exclusively constrained to the hanging wall of the ENE-trending North and South Beddiane faults [36]. From the fault geometry and siting of the MVT orebodies, it is inferred that the South and North Beddiane fault zones constituted favorable conditions for lateral transport and deposition of copper in the faults during supergene mineralization. Supergene copper mineralization consists of surficial, locally highly silicified, Fe- and $\mathrm{Cu}$-cemented breccia of malachite, azurite, chrysocolla, cuprite, native copper, atacamite, connellite, and abundant iron oxide minerals (goethite and hematite) ([5] and this present study; Figure 5D). The presence of sharp-edged azurite crystals lining within the gouge zone indicates deposition after movement along the fault. Pods of remnants' massive chalcopyrite and tetrahedrite have been encountered at the Beddiane mine at a depth of $180 \mathrm{~m}$ [36].

Unlike the Touissit-Bou Beker district, where $\mathrm{Pb}$ dominates largely over $\mathrm{Zn}$ in a mass ratio of 5:1, the Jbel Bou Dahar district contains the largest non-sulfide zinc orebodies, which constitute the historical basis for the development of calamine mining in Morocco. The Jbel Bou Dahar district is also a special case, as both $\mathrm{Pb}-\mathrm{Zn} \pm \mathrm{Cu}$ sulfide and nonsulfide ores \pm barite are currently mined from the numerous mine workings scattered along the flanks of the reefal structure (Figure 3). Calamine grade is highly variable throughout the mining district, ranging from a few percent of combined $\mathrm{Zn}-\mathrm{Pb}$ to more than $30 \%$ $\mathrm{ZnO}$ in the most enriched ore. In this respect, it should be emphasized that the minimum calamine ore grade required to be calcined by the CADETAF facilities is $18 \% \mathrm{ZnO}$, which ultimately allows enrichment up to $45 \% \mathrm{ZnO}$ through roasting. From the mined open pits, digs, and geologic observations, it can be inferred that the calamine ore extends downward as deep as $>200 \mathrm{~m}$, but only calamine orebodies located above the present water table have been or are being exploited by artisanal miners.

In all the studied deposits, non-sulfide mineralization occurs as (1) strata-bound tabular blankets and pods of variable thickness, width, and strike extent and disseminations of millimeter- to centimeter-scale patches resulting from the replacement of both the primary sulfides and the Jurassic host carbonates, (2) oxide boxworks (after sphalerite, Figure 5E), and (3) botryoidal concretions (Figure 5F) to columnar aggregate infills (Figure 6A) of interconnected karst cavities, vugs, veins, and fractures. The dominant ore zone geometry is strata-bound, and boundaries of mineralization correspond with the weathering front within fresh dolomitic limestone. The higher-grade ore zones are deeply oxidized with karstic cavities or fissures filled with variously colored clays, organic debris, lithic fragments derived from the overlying weathered carbonates, and speleothems (Figure 5A). The supergene ore shows different stages of in situ oxidation and replacement of the primary $\mathrm{Pb}-\mathrm{Zn}$-bearing sulfide mineralization and therefore could be assigned to direct replacement type of supergene mineralization [3]. In comparison with replacement ore, for most of the higher-grade orebodies, open-space filling mineralization accounts for a significant proportion of the recovered supergene $\mathrm{Pb}-\mathrm{Zn}$ ore. 

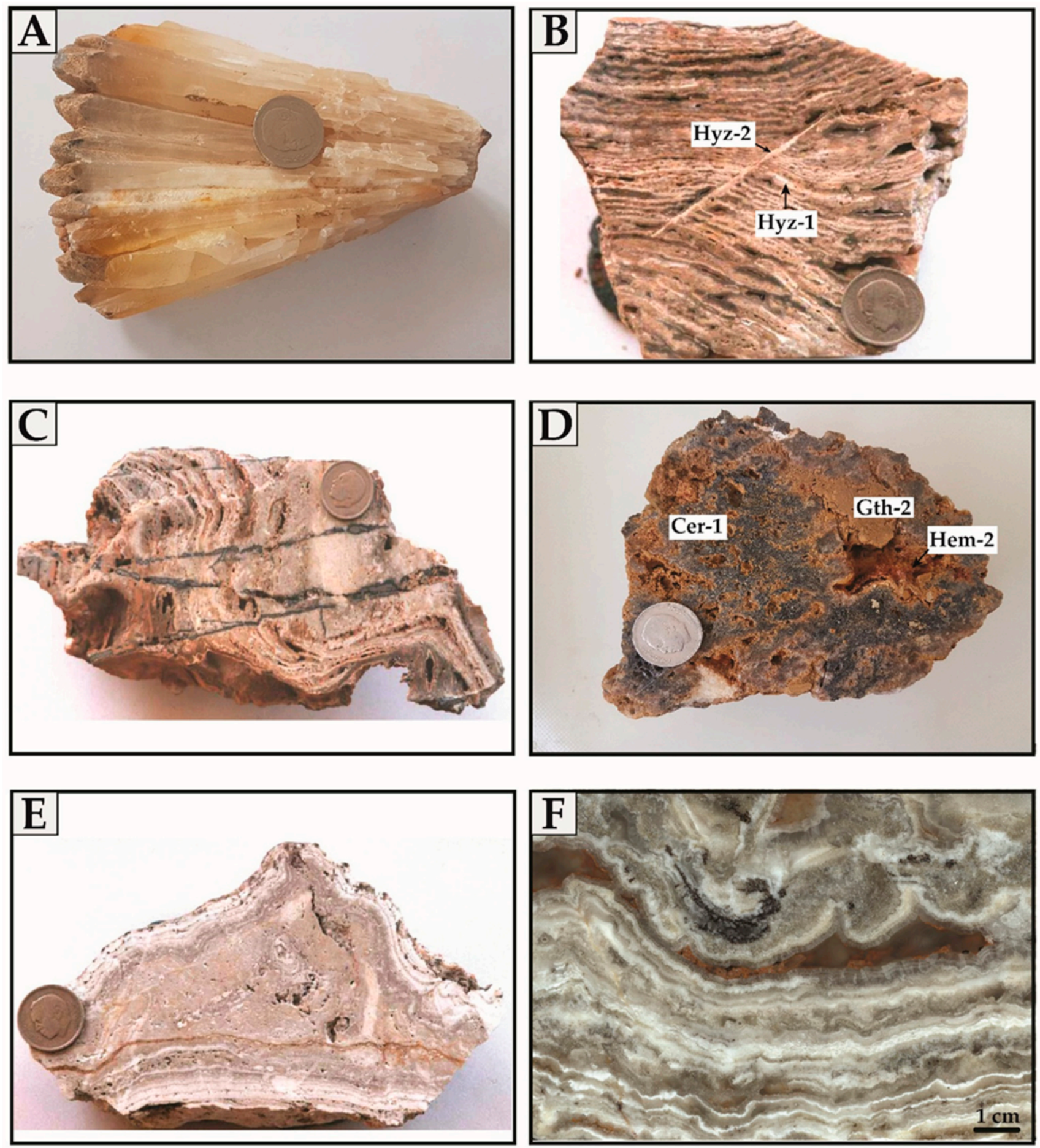

Figure 6. Selected representative rock slab photographs illustrating mineralogical and paragenetic attributes, styles of open-space filling mineralization, and textural variations of the non-sulfide ores from the Jbel Bou Dahar district. (A) Close up of a columnar "palissadic" late-stage calcite. (B) Bedded crustiform calamine ore showing crosscutting relationships. Note the stratiform texture shown by early smithsonite 1 which consists of a succession of subhorizontal white to grayish translucent smithsonite layers which are crosscutted by veinlet of later hydrozincite (Hyz). (C) Stromatolitic-like textured calamine crosscutted by thin veinlets of galena, with this latter being rimmed by dark cerussite (Cer). (D) Massive red calamine ore showing the coexistence of black smithsonite and iron hydr(oxydes) (Gth, Hem). (E) White calamine ore showing stromatolitic-like texture overprinted by the development of numerous mm-sized vacuoles interpreted as "birdeyes" resulting from $\mathrm{CO}_{2}$-degassing. (F) Close up of a crustiform stromatolitic-like textured white calamine ore showing laminations of smithsonite and hydrozincite. 


\subsection{Mineralogy and Geochemistry}

Regardless of the considered deposit and/or district, the oxidized mineral paragenesis consists predominantly of variable proportions of cerussite $\left(\mathrm{PbCO}_{3}\right)$ and smithsonite $\left(\mathrm{ZnCO}_{3}\right)$, whose relative abundances are primarly controlled by the $\mathrm{Pb}: \mathrm{Zn}$ mass ratios of the primary sulfide ore (i.e., $\mathrm{Zn}$-dominant vs. $\mathrm{Pb}$-dominant deposits). Subordinate minerals include anglesite $\left(\mathrm{PbSO}_{4}\right)$, hydrozincite $\left(\mathrm{Zn}_{5}\left(\mathrm{CO}_{3}\right)_{2}(\mathrm{OH})_{6}\right)$, hemimorphite $\left(\mathrm{Zn}_{4} \mathrm{Si}_{2} \mathrm{O}_{7}(\mathrm{OH})_{2} \cdot \mathrm{H}_{2} \mathrm{O}\right)$, willemite $\left(\mathrm{Zn}_{2} \mathrm{SiO}_{4}\right)$, malachite, azurite, and Mn-(hydr)oxides. Calcite, aragonite, gypsum, barite, celestine, and quartz are the most common gangue minerals. These mineral assemblages are typical of those characterizing non-sulfide occurrences derived from MVT deposits (3). Exotic mineral species include vanadinite and wulfenite and, to lesser extent, pyromorphite, manganese oxides (coronadite, cryptomelane, and hollandite), mottramite $\left(\mathrm{PbCu}\left(\mathrm{VO}_{4}\right)(\mathrm{OH})\right)$, paralaurionite $(\mathrm{PbCl}(\mathrm{OH}))$, phosgenite $\left(\mathrm{Pb}_{2} \mathrm{CO}_{3} \mathrm{Cl}_{2}\right)$, and sauconite $\left(\left(\mathrm{Na}_{0.3} \mathrm{Zn}_{3}(\mathrm{Si}, \mathrm{Al})_{4} \mathrm{O}_{10}(\mathrm{OH})_{2} \cdot 4\left(\mathrm{H}_{2} \mathrm{O}\right)\right)[26,30]\right.$. In partially oxidized orebodies, remnants of minor sphalerite, chalcopyrite, and less commonly pyrite and abundant galena are locally preserved within the non-sulfide orebodies being enclosed within by their unaltered carbonate gangue (calcite and dolomite).

The predominant non-sulfide zinc mineral of economic significance is smithsonite, which has been observed in various proportions in every deposit though the higher abundances are reported in the Jbel Bou Dahar mines. In addition to smithsonite, the complete sequence of Zn-bearing phases that collectively define the "calamine" group (Figure 6B,C) include hydrozincite, willemite, hemimorphite, and sauconite, with variable amounts of $\mathrm{Fe}$ (hydr)oxides (goethite and hematite), cerussite, and anglesite. Owing to their mineralogy, the non-sulfide zinc deposits in the Jbel Bou Dahar district and by inference over the entire central and eastern High Atlas are assigned to the carbonate-hosted "calamine" class of [1], in which smithsonite, hydrozincite, willemite, and hemimorphite are the principal zinc-bearing minerals.

Based on the mode of occurrence of mineralization (i.e., replacement vs. open-spacefilling), ore textures, and Zn-bearing mineral assemblages, two distinct types of calamine referred to as "red" and "gray to white" calamine ores are distinguished (Figure 6D,E). The red calamine occurrences are widespread throughout the studied districts and are easily recognizable in surface outcrops owing to their distinctive detrital, "gossanous", and "earthy" appearance, exhibiting locally spongy textures. Their reddish to yellowish color is imputed to the widespread development of superficial blankets of Fe oxyhydroxides (hematite, goethite), which derived from oxidation of preexistent pyrite and/or marcasite. Conversely, the gray to white calamine occurrences are recognizable by their milky chalky appearance although locally transparent to translucent. Textural relationships indicate that the emplacement of the white calamine occurred after the development of the red calamine, in agreement with all the established chronologic reconstitutions for calamine deposits worldwide $[6,19,30,64,65]$. Structural constraints indicate that the emplacement of calamine ore is structurally controlled as most of the orebodies are distributed along the major ENE-trending faults.

Smithsonite is present in all deposits, occurring as fine disseminations variably replacing the sphalerite grains and the carbonate groundmass, as open space infills, and as concretionary crust on dolomitic carbonates (Figure 5F). Direct evidence for the replacive nature of smithsonite is provided by the vertical zonation of the $\mathrm{Pb}-\mathrm{Zn}$ ore, which shows an underlying buried $\mathrm{Pb}-\mathrm{Zn}$ sulfide protore grading upward to an overlying cap of carbonate, iron oxides, and oxyhydroxides ore through a mixed zone of sulfide-carbonate ore. Two generations of smithsonite are distinguished. Smithsonite-1 (Sm-1), which is not very common, is paragenetically related to the "red calamine ore", being intimately associated with Fe oxy-hydroxides. It consists of botryoidal aggregates of brownish-red color crystals with a rugged appearance and is chemically impure with $\mathrm{FeO}$ and $\mathrm{CdO}$ contents below $1 \mathrm{wt} \%$ [5]. Sm-1 shows evidence of in situ oxidation and progressive replacement of both the primary sulfides and the carbonate groundmass. In contrast to Sm-1, the second generation of smithsonite (Sm-2) occurs as transparent rice-shaped infills [65] of microkarsts, 
vein, and fracture networks and as grayish to whitish concretionary aggregates lining walls of the cavities (Figure 5F) and the remnant porosity. Geochemically, Sm-2 displays a quite pure chemical composition approaching the idealized formula $\mathrm{ZnCO}_{3}$.

Primary sphalerite, from which the two generations of smithsonite derived, is characterized by low concentrations of Fe (122-6271 ppm, average $=1349 \pm 1775 \mathrm{ppm}), \mathrm{Cd}$ $(298-1462 \mathrm{ppm}$, average $=814 \pm 38 \mathrm{ppm})$, As $(0.1-84.1 \mathrm{ppm}$, average $=9.5 \pm 25.0 \mathrm{ppm})$, $\mathrm{Sb}(0.0-56.6 \mathrm{ppm}$, average $=9.7 \pm 16.9 \mathrm{ppm})$, and $\mathrm{Pb}(0.1-321.8 \mathrm{ppm}$; average $=70.9 \pm$ $96.5 \mathrm{ppm})$. Ge $(0.28 \pm 0.04 \mathrm{ppm})$ and Ga (5.84 $\pm 8.46 \mathrm{ppm})$ (Table 2) show much lower concentrations than those abundances reported by [31] for the calamine ore (willemite), which approach 1000 ppm for Ge.

Table 2. Representative trace element compositions of sphalerite from Jbel Bou Dahar (JBD) district.

\begin{tabular}{|c|c|c|c|c|c|c|c|c|c|c|c|c|c|c|c|}
\hline Sample No. & Mn & $\mathrm{Fe}$ & $\mathrm{Cd}$ & $\mathrm{Sb}$ & $\mathrm{Cu}$ & $\mathrm{Pb}$ & As & $\mathrm{Ag}$ & Co & In & Ga & $\mathrm{Ge}$ & Se & $\mathrm{Tl}$ & $\mathbf{B i}$ \\
\hline JBD-Sp1 & 2.9 & 1285.9 & 298.1 & 1.2 & 32.1 & 77.8 & 3.3 & 0.00 & 11.9 & 0.00 & 1.59 & 0.02 & 0.000 & 0.000 & 0.000 \\
\hline JBD-Sp2 & 1.8 & 584.6 & 333.2 & 7.7 & 39.1 & 154.4 & 2.3 & 0.81 & 19.4 & 0.00 & 0.03 & 0.01 & 0.001 & 0.010 & 0.000 \\
\hline JBD-Sp3 & 0.1 & 121.6 & 471.9 & 0.2 & 33.7 & 0.1 & 0.1 & 0.03 & 12.6 & 0.01 & 22.08 & 0.00 & 0.031 & 0.000 & 0.000 \\
\hline JBD-Sp4 & 0.1 & 131.9 & 551.4 & 0.3 & 33.8 & 0.1 & 0.1 & 0.02 & 13.6 & 0.02 & 22.18 & 0.00 & 0.030 & 0.000 & 0.000 \\
\hline JBD-Sp5 & 0.9 & 298.9 & 1265.5 & 0.1 & 1.6 & 10.3 & 0.1 & 0.04 & 22.5 & 0.01 & 2.01 & 0.01 & 0.047 & 0.000 & 0.000 \\
\hline JBD-Sp6 & 6.1 & 1696.9 & 877.1 & 5.8 & 31.7 & 30.6 & 1.2 & 0.05 & 23.2 & 0.00 & 0.46 & 0.02 & 0.002 & 0.001 & 0.000 \\
\hline JBD-Sp7 & 0.9 & 372.6 & 799.4 & 4.8 & 17.6 & 15.8 & 0.2 & 0.05 & 44.3 & 0.00 & 8.36 & 0.01 & 0.001 & 0.000 & 0.000 \\
\hline JBD-Sp8 & 1.4 & 390.1 & 926.1 & 0.8 & 6.6 & 102.4 & 1.1 & 0.02 & 37.1 & 0.00 & 5.86 & 0.01 & 0.001 & 0.000 & 0.000 \\
\hline JBD-Sp9 & 5.2 & 1570.1 & 854.1 & 5.5 & 25.2 & 321.8 & 1.1 & 0.08 & 24.3 & 0.00 & 0.98 & 0.03 & 0.008 & 0.000 & 0.001 \\
\hline JBD-Sp10 & 6.8 & 2110.6 & 1462.2 & 56.6 & 98.8 & 10.7 & 11.4 & 3.82 & 39.3 & 0.01 & 0.38 & 0.03 & 0.002 & 0.011 & 0.000 \\
\hline JBD-Sp11 & 5.6 & 6271.3 & 1112.1 & 23.5 & 183.2 & 55.9 & 84.1 & 0.21 & 78.9 & 0.01 & 0.35 & 0.14 & 0.002 & 0.004 & 0.001 \\
\hline
\end{tabular}

Hydrozincite is widespread in all deposits of Jbel Bou Dahar district and to a lesser extent in the Touissit-Bou Beker district. Commonly associated with smithsonite, hydrozincite occurs as needle-shaped crystals locally replacing smithsonite and sphalerite directly and also as whitish millimeter- to decimeter-thick alternating laminae (banded white calamine) defining a "stromatolitic-like" texture (Figure 6F), accompanied locally by botryoidal aggregates filling the remaining cavities and voids on smithsonite.

As for smithsonite and hydrozincite, cerussite has been observed in all deposits, particularly in the Touissit-Bou Beker district, where this mineral constitutes the principal $\mathrm{Pb}$-carbonate phase of economic significance. Where observed, cerussite, together with anglesite, occurs as (i) dark gray massive to partial replacement of the dolomitic host rocks and the associated galena ore, giving rise to earthy or stony "cerussitic" ore (i.e., "cerusite pierreuse" of [5], Cer-1) (Figures 5B and 6C), or (ii) vugs, fractures, and remnant porosity infills, mostly as euhedral crystals of variable dimension (up to several $\mathrm{cm}$ ) $($ Cer-2) filling irregularly distributed druses within the massive galena orebodies down to $150 \mathrm{~m}$ in depth (Figure 7A). Cerussite and anglesite are also observed together within fractures in galena and along grain boundaries. The earliest replacive stony or earthy cerussite (Cer-1) is not chemically pure and contains oxide concentrations that can locally reach $8-10 \mathrm{wt} . \%$ $\mathrm{MgO}$, up to $\sim 3 \mathrm{wt} . \% \mathrm{MnO}$, up to $5-6 \mathrm{wt} . \% \mathrm{FeO}$, and up to $6 \mathrm{wt} . \% \mathrm{CaO}$. The late cerussite (Cer-2), however, is chemically pure, showing little variation in chemistry and approaches the idealized formula $\mathrm{CaCO}_{3}$. 

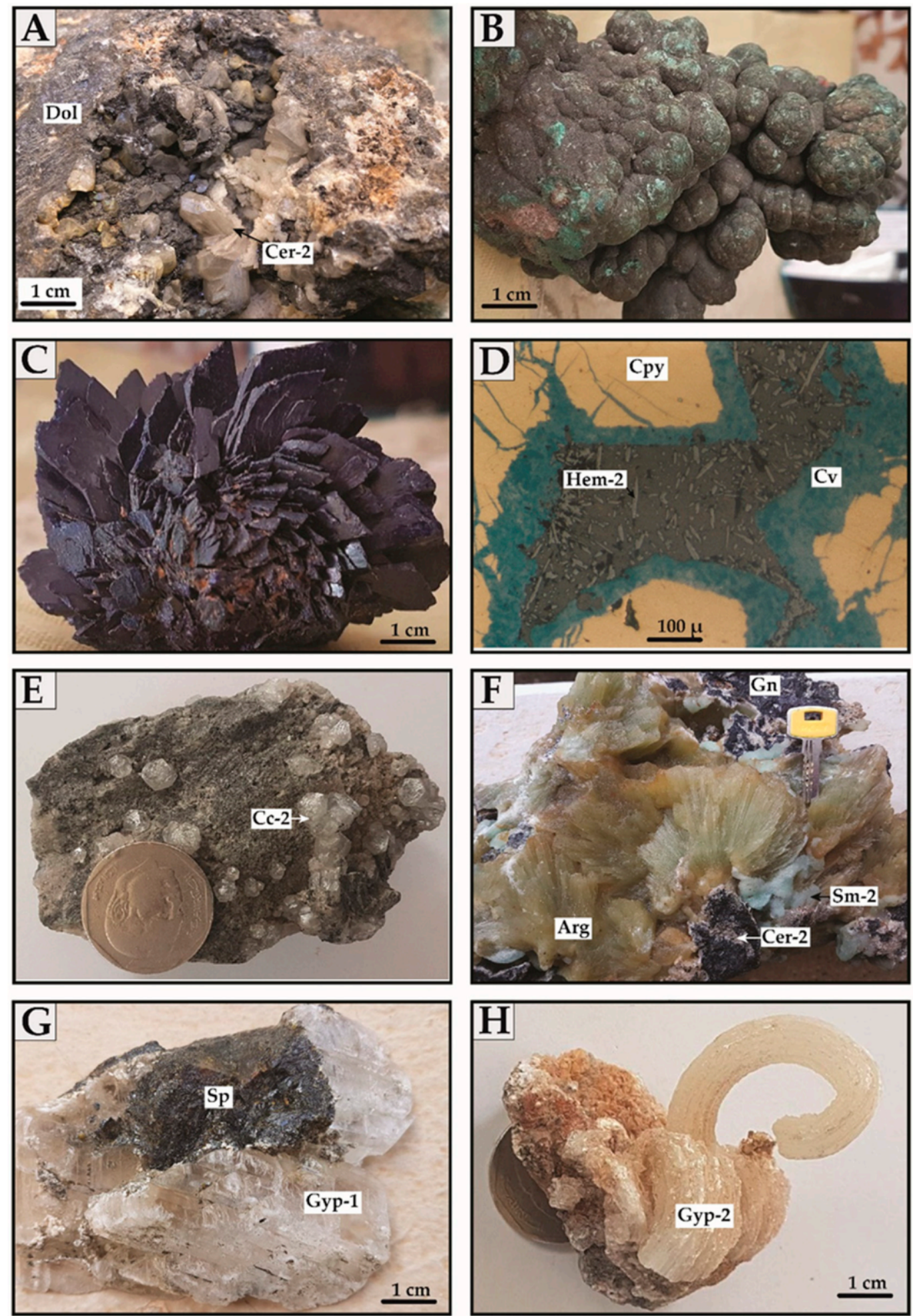

Figure 7. Representative photographs of hand specimens (A-C, E-H) and reflected light microscopy (D) displaying representative aspects of non-sulfide mineralogy, textural variations, and paragenetic attributes from the Touissit-Bou Beker and Jbel Bou Dahar districts. (A). Close up of a cm-wide dissolution cavity filled with euhedral transparent cerussite (Cer, Dol = Dolomite). (B) Botryoidal malachite. (C) Cauliflower-textured azurite. (D) Reflected plane-polarized light photomicrograph of brecciated and altered chalcopyrite (Cpy) with covellite $(\mathrm{Cv})$ and the fractures and grain boundaries. Note also the later development of hematite (Hem) needles within the remaining vugs. (E) Late-stage calcite (Cc-2) encrusted on galena (Gn). (F) Close up of radiating aragonite (Arg) cementing cm-sized fragments of galena partially oxidized to cerussite. (G) Close up of transparent tabular gypsym (Gyp-1) intimately associated with sphalerite (Sp). (H) Late-stage "miscellaneous" to "wired gypsum" (Gyp-2). 
Malachite and azurite (Figure 7B,C), along with covellite (Figure 7D) and chalcocite, occur as partial to complete replacement of $\mathrm{Cu}$-bearing minerals, especially of chalcopyrite and Ag-rich tetrahedrite [5] and are generally associated with cerussite and anglesite. A complex association of iron and manganese oxy-hydroxides (e.g., goethite, hematite, lepidocrocite) and residual $\mathrm{Zn}$-rich clays complete the list of the recognized supergene mineral species. Subordinate mineral species include a wide panel of supergene phases including carbonates silicates (hemimorphite, chrysocolla), oxides (psilomelane, wulfenite, and cuprite), rare phosphates (pyromorphite, scholzite), vanadates (vanadinite, descloizite, and mottramite), arsenates (beudantite, mimetite), and native copper [5]. The main gangue minerals include late-stage calcite (Figure 7E), aragonite (Figure 7F), quartz, gypsum (Figure 7G,H), and celestine. Gypsum, which is widespread in the Touissit-Bou Beker district but less common in Jbel Bou Dahar deposits, occurs either as transparent to translucent euhedral crystals intimately associated with primary sulfides (sphalerite and galena, Figure 7G) (Gypsum 1, Gyp-1) or as replacement crust and stalactitic encrustations lining cave walls (Gypsum 2, Gyp-2) formed at the contact of sulfuric acid and carbonate rocks (Figure 7H). Similarly, late-stage calcite shows different habits, varying from columnar-like radiating aggregates (Figure 6A) through botryoidal precipitates to rhombohedral/scalenohedral crystals (Figure 7E) filling cavities, veins, and fractures.

\subsection{Paragenetic Sequence}

Although no consistent paragenetic sequence can be defined, as the supergene mineral assemblages appear to be the product of multiple overlapping pulses, an idealized paragenetic sequence of mineral deposition within the non-sulfide $\mathrm{Pb}-\mathrm{Zn} \pm \mathrm{Cu}$ mineralization for all deposits is proposed (Figure 8). In summary, the sequence of mineral deposition shows the existence of two main stages of supergene mineralization referred to as "red calamine" and "white calamine" ore stages (Figure 8). A further earlier event characterized by weathering-related processes is also recognized. The proposed succession is consistent with those paragenetic sequences drawn for non-sulfide $\mathrm{Pb}-\mathrm{Zn} \pm \mathrm{Cu}$ deposits worldwide [19,30,66-68].

The earliest stage, referred to as pre-non-sulfide immature "gossanous" stage I, corresponds to the oxidation of pyrite and subsequent formation of yellowish to reddish massive to pulverulent mixture of Fe oxi-hydroxides (hematite, goethite) with a variable proportion of subordinate silicates. The second stage, which constitutes the main stage of sulfide oxidation, accounts for a significant proportion of the calamine ore recovered from all the deposits of the High Atlas calamine province. The initiation of large-scale supergene zone-refining reactions leads to a progressive in situ replacement of all the preexistent sulfides with a very limited transport of the released base metals by sulfide dissolution from the original protore zone. The resulting mineral paragenesis consists predominantly of smithsonite-1, cerussite- 1 and anglesite-1, accompanied by various amounts of willemite1 and Fe oxy-hydroxides (goethite and hematite principally). Sulfide remnants (minor sphalerite and abundant galena) are commonly observed within the non-sulfide protore, together with the unaltered carbonate gangue (calcite and dolomite).

The latest stage of sulfide oxidation is economically the most attractive as it accounts for most of the higher-grade $\mathrm{Zn}$-rich orebodies in all of the investigated deposits of the calamine province of the Central High Atlas. The mineralization occurs as late-phase fillings of cavities, fractures and cementing breccias as well as replacements of earlier phases. The mineralogy is dominated by smithsonite-2, cerussite-2, anglesite-2, and, more importantly, hydrozincite, which characterizes this stage. Owing to their high mobility in comparison to lead, zinc ions were transported farther away from the sulfide precursor and then precipitated distally in cavities or as internal sediment infillings. The resulting wall-rock replacement mineralization (i.e., white calamine ore) is $\mathrm{Zn}$-rich and correlatively $\mathrm{Pb}$ - and Fe-poor, in agreement with previous works of $[3,16]$. 


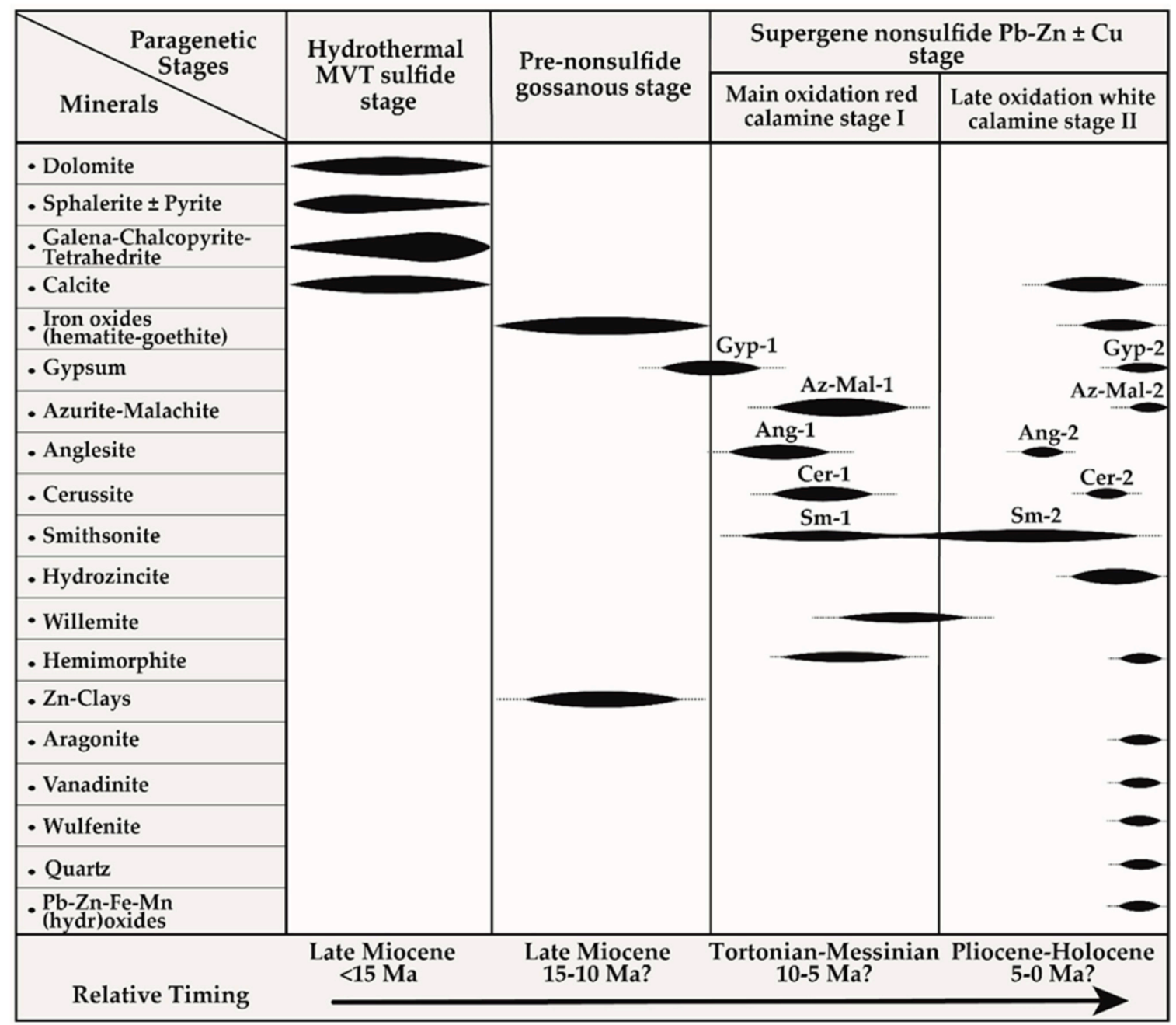

Figure 8. Idealized mineral paragenesis and timing of the hydrothermal sulfide and subsequent meteoric non-sulfide mineralization recognized throughout the carbonate-hosted $\mathrm{Zn}-\mathrm{Pb} \pm \mathrm{Cu}$ deposits of Touissit-Bou Beker and Jbel Bou Dahar districts. Dashed lines represent the uncertainty of appearance of a given mineral in the corresponding stage. Line weight indicates relative abundance of mineral species. Abbreviations: Ang = anglesite, Az = azurite, Cer = cerussite, Gyp = gypsum, $\mathrm{Sm}=$ smithsonite .

\subsection{Carbon and Oxygen Isotope Geochemistry}

The carbon and oxygen isotope datasets comprise a total of 39 samples, including 4 cerussite, 8 smithsonite, 10 calcite, 8 azurite, and 3 malachite. A further set of four gypsum specimens and two single crystals of anglesite and vanadinite were also analyzed for their oxygen isotopic compositions. The recorded $\delta^{13} \mathrm{C}$ and $\delta^{18} \mathrm{O}$ values are indicated in Table 1 and plotted in Figures 9 and 10. 


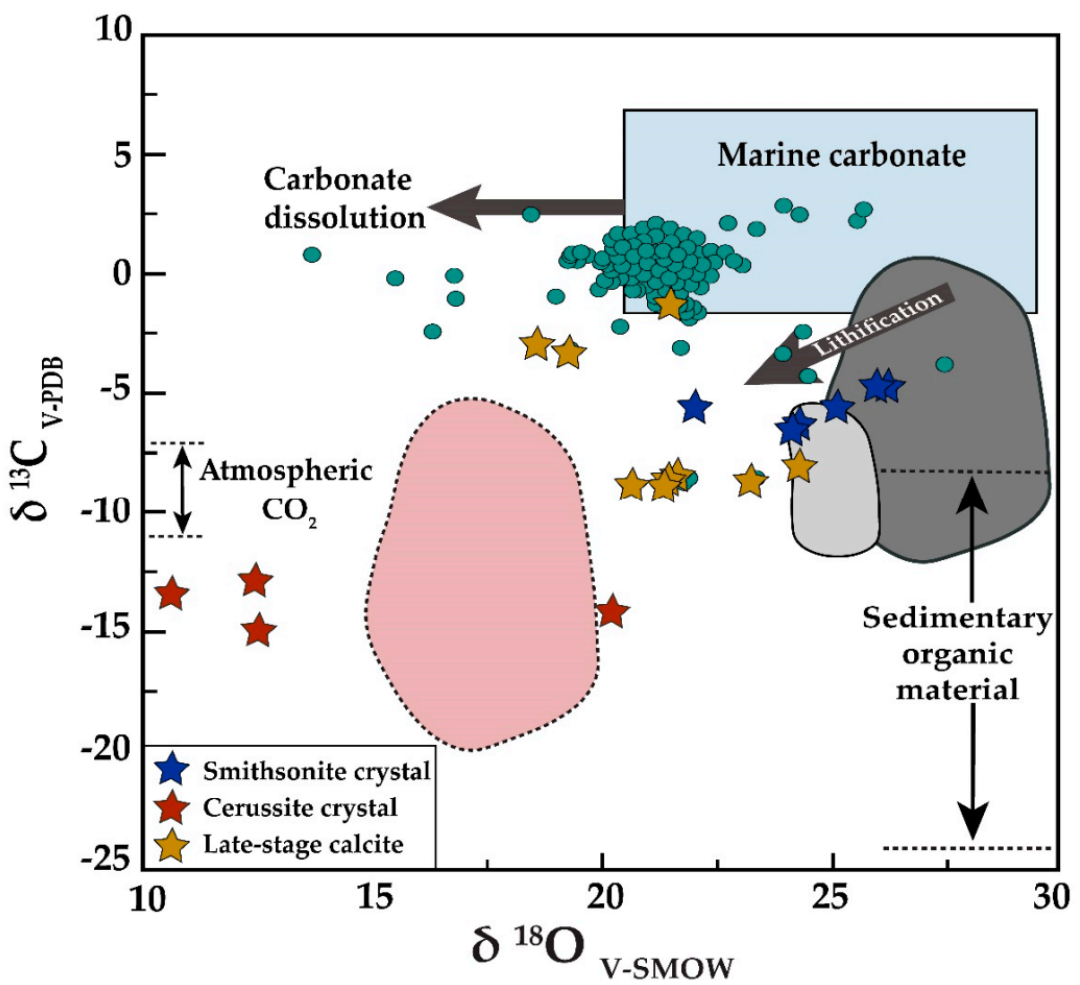

Figure 9. $\delta^{13} \mathrm{C}_{\mathrm{V}-\mathrm{PDB}}$ vs. $\delta^{18} \mathrm{O}_{\mathrm{V}-\mathrm{SMOW}}$ data for supergene carbonate minerals (cerussite, smithsonite, calcite) from various mineralizing stages from the Touissit-Bou Beker and Jbel Bou Dahar districts. The compositional fields of smithsonite (dark grey), calcite (light grey), and cerussite (pink colored) from supergene $\mathrm{Zn}-\mathrm{Pb}$ deposits [59] are indicated for comparison. Composition of Middle Jurassic marine limestone is from $[69,70]$. Arrows show the generalized burial, and meteoric diagenetic trends for carbonates are from [71].

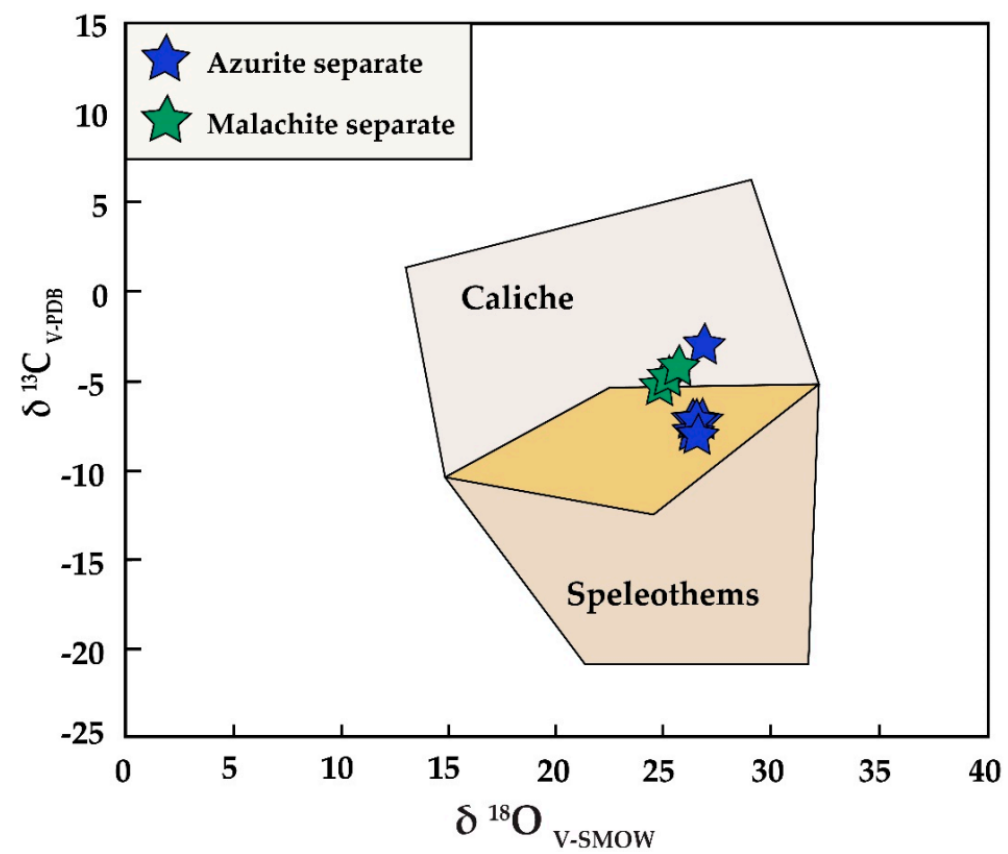

Figure 10. $\delta^{13} \mathrm{C}_{\mathrm{V}-\mathrm{PDB}}$ vs. $\delta^{18} \mathrm{O}_{\mathrm{V}-\mathrm{SMOW}}$ data for natural azurite and malachite from various mineralizing stages from the Touissit-Bou Beker district. The compositional fields of caliche and speleothem are from [62]. 
The $\delta^{13} \mathrm{C}_{\mathrm{V}-\mathrm{PDB}}$ and $\delta^{18} \mathrm{O}_{\mathrm{V}-\mathrm{SMOW}}$ values of cerussite range from -15.1 to $-12.8 \%$ (average $=-13.7 \pm 1.1 \%, \mathrm{n}=4$ ) and 10.4 to $20.2 \%$ o (average $=13.9 \pm 4.3 \%, \mathrm{n}=4$ ), respectively. The $\delta^{13} \mathrm{C}_{\mathrm{V}-\mathrm{PDB}}$ and $\delta^{18} \mathrm{O}_{\mathrm{V}-\mathrm{SMOW}}$ values for smithsonite range from -6.4 to $-1.4 \%$ o (average $=-5.0 \pm 1.7 \%$ o $\mathrm{n}=7$ ) and 21.9 to $25.9 \%$ o (average $=25.2 \pm 2.2 \%, \mathrm{n}=$ 7), respectively (Table 1). Overall, the isotopic compositions of smithsonite fall within the compositional field of the typical supergene smithsonite (Figure 9), although some of the isotopic compositions plot outside this field, toward lower $\delta^{18} \mathrm{O}_{\mathrm{V}-\mathrm{SMOW}}$ values. Conversely, none of the $\delta^{18} \mathrm{O}_{\mathrm{V}-\mathrm{SMOW}}$ values of cerussite fit within the range of typical isotopic compositions that characterize the compositional field of supergene cerussite (Figure 9). Instead, most of the oxygen isotope signatures of cerussite are shifted toward oxygen isotope ratios characteristic of a hydrothermal overprint, but $\delta^{13} \mathrm{C}_{\mathrm{V}-\mathrm{PDB}}$ ratios typical of supergene cerussite (Table 1; Figure 9). Such isotopic patterns have also been documented for cerussite from the Tunisian Bou Jaber deposit [72].

The azurite crystals from the Touissit-Bou Beker district yield $\delta^{18} \mathrm{O}_{\text {SMOW }}$ values of 26.2 to $26.8 \%$ o (average $=26.3 \pm 0.2 \%$, $\mathrm{n}=7$ ), whereas their corresponding $\delta^{13} \mathrm{C}$ ratios range from -7.7 to $-2.8 \%$ (average $=-6.9 \pm 1.8 \%, \mathrm{n}=7$ ) (Table 1 ). The three malachite specimens show $\delta^{13} \mathrm{C}$ and $\delta^{18} \mathrm{O}_{\text {SMOW }}$ values of -5.2 to $-4.1 \%$ o (average $=-4.6 \pm 0.6 \%$, $\mathrm{n}=3$ ) and 25.2 to 25.7 (average $=25.3 \pm 0.4 \%$ o $n=7$ ), respectively. Overall, these isotopic compositions are similar to those determined for natural azurite and malachite worldwide and plot within the caliche field, as defined by [62] (Figure 10). The single anglesite and vanadinite samples display, however, contrasting $\delta^{18} \mathrm{O}_{\mathrm{SMOW}}$ values of 12.5 and $33.3 \%$, respectively (Table 1 ).

The late fracture- and cavity-filling calcite from both the Touissit-Bou Beker and Jbel

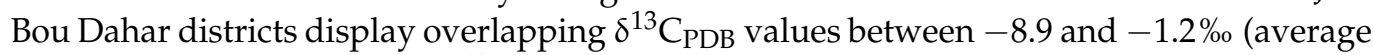
$=-6.1 \pm 3.1 \%, \mathrm{n}=10$ ) and $\delta^{18} \mathrm{O}_{\mathrm{SMOW}}$ ratios between 18.6 and $24.4 \%$ o (average $=21.5 \pm$ $1.7 \%$, $\mathrm{n}=10$ ) (Figure 9). Overall, these isotopic compositions plot within the compositional range that characterizes supergene late-stage calcite elsewhere. In comparison to the Jurassic host carbonates and associated hydrothermal dolomite and calcite $[5,29]$, the isotopic compositions of late-stage calcite show substantially lower and distinctive negative $\delta^{13} \mathrm{C}$ values (Figure 9). Of particular interest is the temporal trend displayed by the distribution of $\delta^{13} \mathrm{C}$ and $\delta^{18} \mathrm{O}$ ratios of smithsonite and cerussite, which shows a concomitant increase in $\delta^{13} \mathrm{C}$ and $\delta^{18} \mathrm{O}$ values with advancing paragenetic sequence (i.e., from Sm-1 and Cer-1 to Sm-2 and Cer-2) (Figure 9). A similar pattern is also displayed by the distribution of $\delta^{13} \mathrm{C}$ and $\delta^{18} \mathrm{O}$ values of coexisting azurite, malachite, and late-stage calcite, which shows an overall increase in $\delta^{13} \mathrm{C}$ and $\delta^{18} \mathrm{O}$ values from older azurite to younger calcite through intermediate malachite (Table 1$)$.

Finally, gypsum from both the Touissit-Bou Beker and Jbel Bou Dahar districts has $\delta^{18} \mathrm{O}$ values of 21.9 to $0.6 \%$ o (mean $=7.0 \pm 9.6 \%$, $\mathrm{n}=4$ ). Similar to the evolutionary trends displayed by the $\delta^{13} \mathrm{C}$ and $\delta^{18} \mathrm{O}$ values of smithsonite and cerussite, as well as azurite, malachite, and late-stage calcite, the distribution of the oxygen isotopic compositions of gypsum show distinct temporal variation. This variation is expressed by an overall increase in $\delta^{18} \mathrm{O}_{\mathrm{SMOW}}$ values with advancing paragenetic sequence toward younger sulfate generation. In this respect, it is noteworthy that early gypsum (Gyp-1) derived from in situ oxidation of sphalerite displays $\delta^{18} \mathrm{O}_{\text {SMOW }}$ value of $0.6 \%$ whereas late-stage wall-rock replacement gypsum (Gyp-2) yields lower $\delta^{18} \mathrm{O}_{\mathrm{SMOW}}$ ratios of 2.4 and $3.7 \%$ (Table 1).

\subsection{Sulfur Isotope Geochemistry}

A total of 11 gypsum specimens along with five late-stage pyrite separates from the different non-sulfide orebodies of the Touissit-Bou Beker and Jbel Bou Dahar districts were analyzed for their sulfur isotope compositions (Table 1).

The gypsum samples display a wide range of $\delta^{34} S$ values from -15.8 to $9.6 \%$ (average $=-3.5 \pm 9.6 \%$ o $\mathrm{n}=11$ ), with the highest ratios characterizing the early gypsum (i.e., Gyp-1) from the red calamine ore stage and the lowest values from the late wall-rock replacement gypsum (i.e., Gyp-2) (Table 1). In this respect, it is noteworthy that all of the $\delta^{34} S$ values of 
Gyp-1 are positive, ranging from 2.3 to $9.6 \%$ (average $=6.0 \pm 2.6 \%, n=5$ ), whereas values from Gyp-2 are all negative and vary between -15.8 and $-6.2 \%$ (average $=-11.3 \pm 3.9 \%$, $\mathrm{n}=6$ ). The $\delta^{34} \mathrm{~S}$ values of late-stage pyrite whose precipitation is related to the collapse of the hydrothermal MVT system and the initial episode of exhumation and weathering of sulfides are all negative, ranging from -16.8 to $-12.6 \%$ (average $=-15.8 \pm 1.8 \%, n=5$ ). Overall, $\delta^{34} \mathrm{~S}$ values of gypsum and pyrite are distinctly below the range of sulfur isotopic compositions for Jurassic seawater sulfate (i.e., 13 to $20 \%$; $[73,74]$ ).

\section{Discussion}

Owing to their strong buffering capacity, carbonate host rocks constitute ideal protoliths for the formation of supergene non-sulfide $\mathrm{Zn}-\mathrm{Pb}$ ores. The distribution of the resulting mineral assemblages is controlled primarily by the initial mineralogy; the composition and flow rates of groundwater; the tectonic evolution, which triggers uplift; uncapping and oxidation of sulfide-rich protore; and climate conditions prevailing at the time of sulfide alteration $[1,3,13]$. The presence of appreciable amounts of pyrite in the alteration zones seems to constitute the best conditions for supergene enrichment as the oxidation of pyrite makes the percolating water more acidic and consequently the replacement of sulfides by supergene minerals more effective. Moreover, fluctuation in the depth of the water table is also an important factor that triggers supergene alteration as the rise and fall of the water table introduces oxygenated water to the primary sulfide body, driving oxidation reactions. Similarly, a climate with alternating wet and dry seasons could promote the formation of weathering and oxidizing solutions, which ultimately would lead to the development of karst networks and replacement of the sulfides [3]. Equally important, uplift and longwavelength vertical movements [15,32,75-78] may lead to enhanced fracturing of the host rock, creating preferential pathways for the downward and lateral flow of metal-bearing groundwaters and consequently migration of the supergene alteration front.

\subsection{Origin of the Supergene Mineralizing Fluid(s)}

Field observations along with mineralogic and petrographic examinations show that the primary $\mathrm{Pb}-\mathrm{Zn} \pm \mathrm{Cu}$ ores are intensely weathered and strongly oxidized. Textural evidences for oxidation and replacement of primary sulfides by low-temperature and low-pressure non-sulfide mineral assemblages include development of reaction fronts, the stalactitic, columnar, and concretionary structures shown by late-stage calcite, smithsonite, and hydrozincite. Further evidence for the involvement of widespread and extensive recent meteoric alteration as the trigger for the oxidation of primary sulfide mineralization includes the development of vertical karsts displaying morphological features associated with normal meteoric speleogenesis (soil carbonates and speleothems). Additionally, the intense and widespread reddening of surface outcrops and internal sediment infills, the ubiquitous occurrence of sandy dolomite, and more importantly the extremely light carbon and oxygen isotope compositions shown by late-stage calcite, which indicate meteoric oxidation of organic matter as shown below, reflect meteoric alteration. Altogether, these textural and mineralogic characteristics indicate that the non-sulfide mineralization from the Touissit-Bou Beker and Jbel Bou Dahar districts precipitated from downward percolating groundwaters of meteoric origin in either a supergene or a low-temperature environment.

In this respect, carbon and oxygen isotope compositions of the $\mathrm{Pb}-\mathrm{Zn} \pm \mathrm{Cu}$-bearing carbonates provide useful information on the fluid characteristics responsible for precipitation of non-sulfide minerals and indirectly constrain the climatic environment that prevailed at the time of deposition (e.g., [19] and references therein). The obtained $\delta^{13} \mathrm{C}$ and $\delta^{18} \mathrm{O}$ values of smithsonite, cerussite, azurite, malachite, and late-stage calcite from the two investigated districts form distinct clusters whose overall isotopic signatures plot in the supergene compositional fields of cerussite, smithsonite, azurite-malachite, and late-stage calcite as defined by [59,62] (Figures 9 and 10). The carbon and oxygen isotope compositions of the Jurassic carbonate host rocks are, however, consistent with 
altered carbonates that underwent isotopic re-equilibration during deep burial fluid-rock interaction [5] (Figure 9).

Assuming that the coexisting cerussite and smithsonite precipitated under equilibrium exchange conditions, the oxygen isotope composition and related temperature of the supergene ore-forming fluid $\left(\delta^{18} \mathrm{O}^{\mathrm{f}} \mathrm{V}\right.$-SMOW) can be calculated using the cerussite-water (1000 $\left.\ln \alpha_{\text {cerussite-water }}=2.29\left(10^{6} / \mathrm{T}^{2}\right)-3.56\right)$ fractionation equation of [59] and the smithsonitewater $\left(1000 \ln \alpha_{\text {smithsonite-water }}=3.21\left(10^{6} / \mathrm{T}^{2}\right)-3,63\right)$ equation of [60] (T given in Kelvin). By doing so, the calculated $\delta^{18} \mathrm{O}^{\mathrm{f}} \mathrm{V}$-SMOW and related temperature from the paired samples TB4.1 and TB4.2 (Table 1 ) are $-8.6 \%$ and $25{ }^{\circ} \mathrm{C}$, respectively. In this respect, it is noteworthy that the calculated $\delta^{18} \mathrm{O}_{\mathrm{V}}^{\mathrm{f}}$-SMOW and ambient temperature values match perfectly, within error, the mean isotopic value of $-8 \%$, which characterizes the present-day $\delta^{18} \mathrm{O}$ value of meteoric waters in the Atlas system [79-81]. More importantly, the oxygen isotope thermometry of azurite, malachite and late-stage calcite, listed in order of their appearance from oldest to youngest and assuming a local meteoric water value of $-8 \%$, indicates decreasing temperature of formation over time from 34 to $19^{\circ} \mathrm{C}$ (Table 1). Overall, these calculated temperatures are similar to those determined for smithsonite, cerussite, and azurite-malachite in other base metal supergene deposits worldwide $\left(11-35^{\circ} \mathrm{C}\right.$, avg $\left.20^{\circ} \mathrm{C} ;[13,59,68]\right)$ and are in agreement with the continental environment in a temperate climate $[68,82]$. Cerussite oxygen isotope thermometry, suggesting temperatures above ambient air temperatures $\left(>30^{\circ} \mathrm{C}\right)$ (Table 1$)$, reflects minor heat production by exothermic oxidation of sulfides.

\subsection{Source(s) of Carbon and Sulfur: Evidence for Microbial Activity}

The broad range of $\delta^{13} \mathrm{C}$ values of smithsonite, cerussite, azurite, malachite, and latestage calcite, ranging from $-1.2 \%$ to as low as $-15.1 \%$ (Table 1 ), indicates contributions from various carbon sources. In this regard, it is noteworthy that the obtained $\delta^{13} \mathrm{C}$ ratios are intermediate between the isotopic compositions of Jurassic marine limestones (i.e., 0 $2 \% ;[69,70])$, organic matter $\left(\delta^{13} \mathrm{C}=-24 \% ;[5]\right)$, and atmospheric carbon $\left(\delta^{13} \mathrm{C}=-7 \%\right.$; [83] $)$ (Figure 9). The negative values recorded for $\delta^{13} \mathrm{C}$ (Table 1) suggest that most of the carbon present during supergene oxidation and subsequent $\mathrm{Pb}-\mathrm{Zn} \pm \mathrm{Cu}$ carbonate formation was derived from different degrees of mixing along the fluid flow path between a ${ }^{13} \mathrm{C}$-depleted carbon source derived from the decomposition of $C_{3}\left({ }^{13} \mathrm{C}=-32.0\right.$ to $-25.0 \%$; [84] $)$ and/or $C_{4}$ surface vegetation $\left(\delta^{13} \mathrm{C}=-14.0\right.$ to $-10.0 \%$; [85]), atmospheric carbon $\left(\delta^{13} \mathrm{C}=\right.$ $-7 \%$; [83]), and dissolution of the Jurassic carbonate host rocks. While the dissolution of the local carbonate rocks and atmospheric carbon undoubtedly makes a contribution, there is a clear relationship between oxygen and carbon isotope values that indicate a diagenetic or lithification overprint (Figure 9). Irrespective of the exact mechanism for such trends, the leading contenders are bacteria and archaea metabolism and deep basin fluid mixing, e.g., $[64,65]$.

In this respect, it is well documented that colonies of chemolithotrophic bacteria and archaea (i) greatly accelerate the alteration of primary sulfide minerals (e.g., $[9,86,87])$, and (ii) are associated with the formation of speleothems in meteoric environment $[23,24]$. As the precipitation of azurite requires partial pressures of $\mathrm{CO}_{2}$ that greatly exceed present atmospheric levels [86-88], this precludes a carbon source in equilibrium with the atmosphere for at least a portion of the supergene period. Indeed, the lighter $\delta^{13} \mathrm{C}$ compositions displayed by all the analyzed carbonates from the studied districts (Table 1) are suggestive of the involvement of significant biological carbon input in the mineralizing process. Further support for the involvement of a biological source in the formation of the supergene mineralization at the Touissit-Bou Beker and Jbel Bou Dahar districts is provided by the light sulfur isotopic compositions shown by Gyp-2 (Table 1). In fact, the highly negative $\delta^{34} S_{\text {Gyp-2 }}$ values of $-15.8 \%$ to $-6.2 \%$ are interpreted to have resulted from isotopic fractionation during multi-stage microbial oxidation of primary sulfide, at different rates of oxygen availability at or near the water table (open vs. closed reservoirs with respect to oxygen), given that most bacteria and archaea associated with supergene processes are 
found near the water table and are thermophilic, flourishing deep in the oxidation zone at temperatures above ambient (e.g., [89]). Accordingly, Gyp-2 is interpreted to have been produced by microbially mediated oxidation of sulfides as a result of the reaction between sulfuric acid $\left(\mathrm{H}_{2} \mathrm{SO}_{4}\right)$ and the carbonate host rocks. In this regard, it is well documented that phototrophic sulfide oxidation can cause ${ }^{34} \mathrm{~S}$ depletions of up to $\sim 4 \%$, or even higher, for $\delta^{34} S$ [90], consistent with the sulfur isotope data reported in this study.

Moreover, the occurrence of the "stromatolitic" and "peloïdal" textures exhibited by the Jbel Bou Dahar "calamine" ore (Figures 6F and 11A), which are remarkably similar to the present-day-forming stromatolites [91], provide ample evidence for the involvement of a biologically controlled mechanism as the main driving process that triggered the supergene mineralization at Jbel Bou Dahar and Touissit-Bou Beker districts. Even though these fabrics resemble the collomorph textures commonly described in both hydrothermal and supergene deposits, their microbial-mediated origin has been demonstrated (e.g., [22] and references therein). In fact, the development of these laminated rhythmically banded macrostructures that are very similar to nanotextures observed in recent bacterial biofilms are interpreted as fossil microbial mats that resulted from in situ metabolic products of sulfate-reducing/oxidizing bacteria and archaea (e.g., [22-24]). Similarly, the aforementioned macro- and microstructures are comparable to those described in biologically controlled hydrozincite-bearing mineralization whose genesis has been linked to photosynthetic alkalinization of the cyanobacterial cell surface during the seasonal alternation between spring and summer [92-94]. More interestingly, the stromatolitic- to peloïdallike textured smithsonite, which consists of a layered succession of alternating $\mathrm{mm}$ - to $\mathrm{cm}$-thick laminae of white and colorless hydrozincite and smithsonite-2 (Figure 11B,C), could reflect seasonal variations in temperature and fluctuations in $\mathrm{pH}$. In this regard, EDS analyses show that compositional variations in $\mathrm{Ca}, \mathrm{O}$, and $\mathrm{Zn}$ contents (Figure 11D) between the alternating white and colorless mirofabrics could be attributed to calcification of cyanobacterial sheaths related to photosynthetic activity, which, in turn, is related to seasonal variations. While debate remains open on the utility of texture as a biogenic indicator, and despite the fact that interpretation of the aforementioned textures may evolve over time, our observations should be considered for the benefit of future researchers and their interpretations.

In summary, we suggest that the combined widespread occurrence of the biogenic rhythmically banded macrotextures, along with the lighter carbon and sulfur isotope compositions shown by the analyzed carbonates, are consistent with the involvement of chemolithotrophic bacteria and archaea in the formation of the Atlasic supergene carbonatehosted $\mathrm{Pb}-\mathrm{Zn}$ mineralization. 

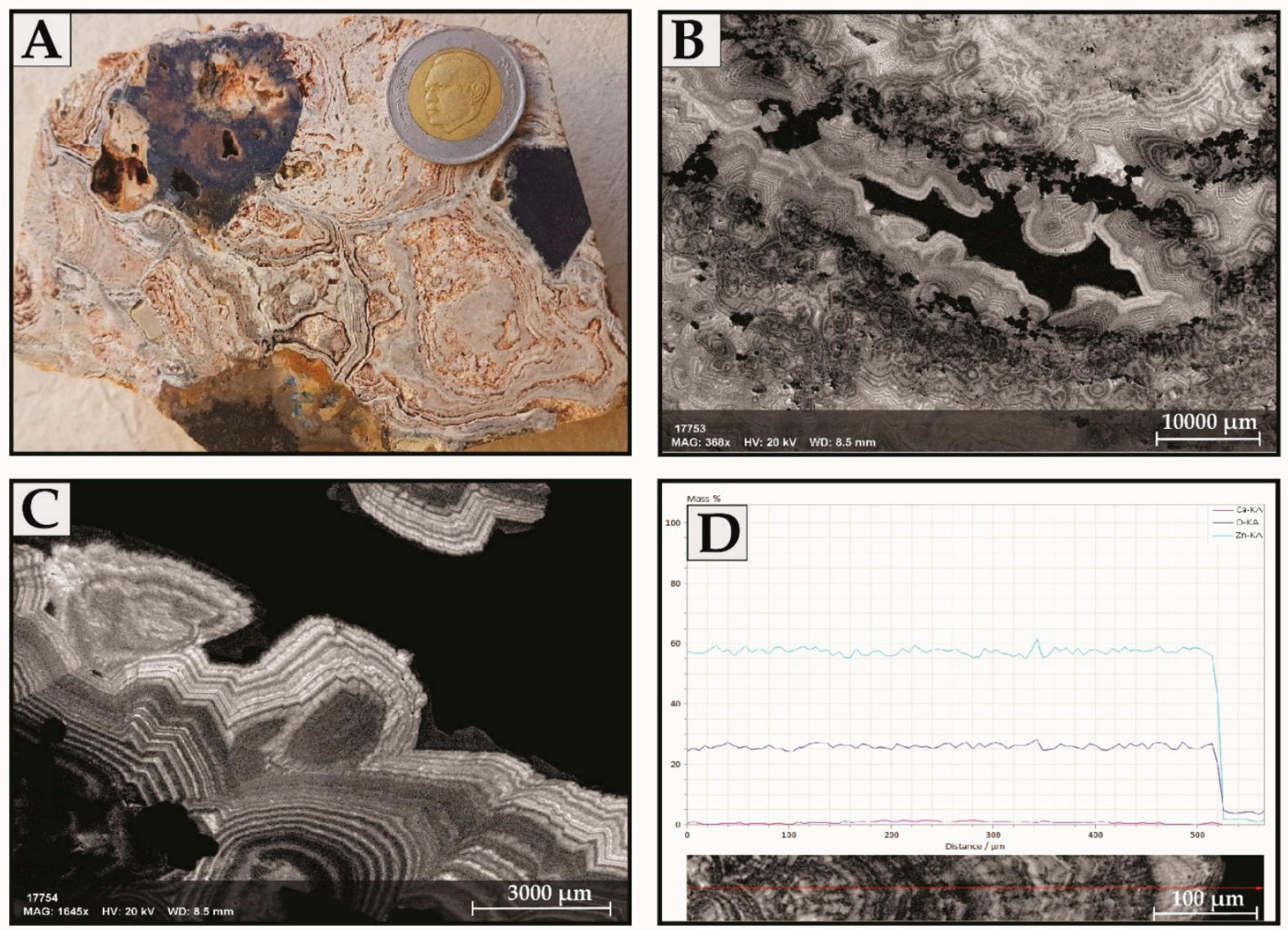

Figure 11. Hand samples and cathodoluminescence images of the banded white calamine ore. (A) Hand sample of white calamine ore from the Jbel Bou Dahar district showing a well-developed "oolitic" to "oncolytic" texture similar to the columnar build-ups produced by modern shallow subtidal stromatolites [90]. (B) Cathodoluminescence (CL) microphotograph of white calamine ore from Jbel Bou Dahar district showing a stromatolitic-like texture materialized by an alternation of mm-thick crusts of smithsonite and hydrozincite. The laminations (i.e., crusts) are interpreted to represent calcified biofilms (Type 2 mats) as defined by [90]. (C) Closeup of the layered stromatolitic-like textured white calamine ore from the Jbel Bou Dahar district showing cycling between smithsonite and hydrozincite. (D) Distribution of Ca, O, and Zn abundances as a function of layering.

\subsection{Proposed Evolution of the Atlasic Non-Sulfide $\mathrm{Pb}-\mathrm{Zn} \pm \mathrm{Cu}$ Deposits}

Field evidence, mineralogical observations, and stable isotope $(C, O, S)$ geochemistry indicate that the supergene $\mathrm{Pb}-\mathrm{Zn} \pm \mathrm{Cu}$ mineralization at Touissit-Bou Beker and Jbel Bou Dahar districts occurred during two main contrasting supergene mineralizing events (i.e., "red calamine" vs. "white calamine" stages). Both events were preceded by development of an earlier immature "gossanous" weathering-related stage. All three stages probably occurred synchronously with the last uplift stage related to the Atlasic orogeny, given that the non-sulfide mineralization shows no evidence of deformation and is therefore interpreted to postdate the Atlasic regional metamorphism and deformation of the Jurassic carbonate rocks.

The exhumation of the Jurassic carbonate platform and the associated sulfide orebodies from late Miocene to present facilitated the downward infiltration of meteoric fluids, oxidation of sulfides and subsequent non-sulfide formation. The resulting lowtemperature, low-pressure mineral assemblages precipitated predominantly as open-space infills (pore space, veins, open fractures, and breccia zones) and also as replacement of carbonate precursors. Although the age(s) of supergene alteration in the studied districts remains poorly constrained, published radiometric ages (Ar-Ar on jarosite, [95] and refer- 
ences therein $[96,97])$ along with thermochronological data from adjacent lithostructural domains [42-44,96-101] indicate that the emplacement of the non-sulfide mineralization likely occurred during the late Miocene (Messinian-Tortonian), Pliocene, and between the late Pleistocene and Holocene, under wet to semi-arid to arid climatic conditions. Arid conditions seem to have prevailed during the last tens of millions of years $[102,103]$ in the Mediterranean area, although alternating wet and arid conditions have been reported $[104,105]$. Uplift and increasing aridity would progressively lower water tables, possibly with substantial seasonal fluctuations in a monsoonal climate, enhancing the effectiveness of the dissolution and the leaching of base metals, especially $\mathrm{Zn}$ and $\mathrm{Cu}$, from the sulfide orebodies. As a result, downward moving surface water, charged with oxygen, percolates through a thicker rock column in the vadose zone between the surface and the water table. This setting provided more frequent replenishment of oxygen to the primary sulfide body, resulting in both a larger degree and a greater thickness of supergene alteration $[106,107]$. These favorable conditions would have promoted deep weathering of the sulfide orebodies and the production of highly acidic fluids, owing to widespread occurrence of pyrite and organic matter within the Jurassic carbonate host rocks.

The influx of the resulting acidic fluids into the carbonate host rocks triggered deep weathering and karst formation, allowing supergene mineralization to extend down dip in the carbonate rocks for at least several hundred meters and vertically for a similar distance in steep structural zones. Equally important, the highly acidic chemistry of the supergene fluids allowed these fluids to progressively leach and transport $\mathrm{Zn}$ and $\mathrm{Cu}$ and, to a lesser extent, $\mathrm{Pb}$ owing to its low mobility. Higher-grade mineralization could have been generated by a supergene "zone refining" process, whereby $\mathrm{Zn}, \mathrm{Cu}$, and, to a lesser extent, $\mathrm{Pb}$ are progressively dissolved and then reprecipitated within secondary trap sites. Galena seems to be more resistant to the oxidizing groundwater than sphalerite and chalcopyrite and can thus occur in association with smithsonite, hydrozincite, and hemimorphite.

The experimental work of $[108,109]$ showed that temperature, $\mathrm{pH}$, activity of $\mathrm{CO}_{2}$ and $\mathrm{SiO}_{2}$ within the ambient groundwater, and concentrations of $\mathrm{Zn}$ and $\mathrm{Pb}$ in solution constitute the principal factors in determining the paragenesis of $\mathrm{Zn}, \mathrm{Pb}$, and $\mathrm{Cu}$ nonsulfides and their spatial distribution. Based on the abovementioned studies and building upon recently published literature (e.g., [6]), we propose a three-stage model for the genesis of the Moroccan non-sulfide $\mathrm{Pb}-\mathrm{Zn} \pm \mathrm{Cu}$ deposits, all of which are coincident with the $\mathrm{D}_{3}$ event of [42] as the primary MVT mineralization (protore) has been dated $<15 \mathrm{Ma}[5,26,28]$. In this respect, it should be emphasized that large-scale, vertical, positive movements were able to produce uncapping and weathering of the primary hypogene sulfides by creating a gradient for the percolation of meteoric fluids. In Morocco, weathering episodes have been related to four main Atlasic geodynamic events referred to as $\mathrm{D}_{0}$ (Late Cretaceous), $\mathrm{D}_{1}$ (Late Eocene), $\mathrm{D}_{2}$ (Early Miocene), and Late Miocene to Recent, consistent with the conclusions of $[30,42,73,110-112]$.

\subsection{Early Pre-Non-Sulfide Gossanous Stage}

The earlier phase of weathering, which resulted in the development of earthy yellowish to reddish goethite- and hematite-rich gossanous rocks, represents the transitional stage that encompasses the time span between the waning stage related to the emplacement of MVT mineralization dated at $<15 \mathrm{Ma}[5,28]$ and the initial episode of exhumation and weathering of sulfides in concert with the latest Atlasic phase of tectonic uplift in the late Miocene ( $10 \mathrm{Ma}, \mathrm{D}_{3}$ of [42]). During this early stage, the occurrence of pyrite has been critical in producing sufficient circulating acid fluids and favoring the high metal concentration in the aqueous solutions ([14]). The presence of pyrite is therefore considered a prerequisite for the development of the two following supergene mineralizing stages, the red calamine and the white calamine ore stages. The oxidation of pyrite will prepare the ground for future non-sulfide mineralization by creating additional secondary porosity and providing the required metals (i.e, $\mathrm{Zn}, \mathrm{Cu}$, and $\mathrm{Pb}$ ) for the ore. Although sphalerite, 
chalcopyrite, and galena are very susceptible to oxidation [113,114], they produce relatively small quantities of acid sulfate-bearing solutions compared to iron sulfides [88].

During this initial stage, oxidation of pyrite constituted the driving force that led to the generation of strongly oxidized and acidic fluids, which ultimately promoted the leaching of most base metals, such as $\mathrm{Zn}$ and $\mathrm{Cu}$, and alkalis from their host rocks with the catalytic participation of sulfide-oxidizing bacteria and archaea. The released metals will migrate away from the sulfide precursor, guided by the high permeability of the host rocks, the ENE- and E-W-trending steeply dipping dilational faults, and the lowered water table and seasonal flushing. The light sulfur isotopic compositions shown by late-stage pyrite $\left(\delta^{34} \mathrm{~S}=-16.8\right.$ to $-16.2 \%$, average $\left.=-15.8 \pm 1.8 \%, \mathrm{n}=5\right)$, whose precipitation is interpreted to have occurred during the collapse of the MVT hydrothermal system and its shift to supergene conditions [28], strongly support the involvement of low-temperature bacteriogenically mediated processes in the oxidation of pyrite. At this stage, the temperature of the shallow subsurface acidic fluids was probably higher than ambient temperatures, as indicated by the crystallographic constraints of the paragenetically related goethite, which indicate temperatures up to $50^{\circ} \mathrm{C}$ [115].

Except for the radiochronological ages provided by [32], who used paleomagnetism to timely constrain the supergene oxidation episodes in the High Atlas, no other direct radiometric ages on the non-sulfide mineral phases from the Touissit-Bou Beker and Jbel Bou Dahar districts are yet available. By regional geological correlations [42] and comparison to equivalent dated supergene ore deposit types in the nearby Mediterranean basin [97], the first episode of oxidation described in this study could have occurred synchronously with the latest phase of tectonic uplift that affected the High Atlas system at $10 \mathrm{Ma}$ (Tortonian-Messinian time [42]).

\subsection{Main Stage of Sulfide Oxidation: The "Red Calamine" Ore Stage}

During this stage, which accounts for significant amounts of the extracted non-sulfide ore in the Touissit-Bou Beker and Jbel Bou Dahar districts, large-scale supergene zonerefining reactions led to a progressive replacement of all the preexistent sulfides, including sphalerite, chalcopyrite, and, to a lesser extent, galena, as $\mathrm{Zn}^{2+}$ and $\mathrm{Cu}^{2+}$ are more mobile than $\mathrm{Pb}^{2+}$ in the supergene environment $[14,116]$. Transport of $\mathrm{Zn}$ and $\mathrm{Cu}$ out of the sulfide orebody was facilitated by a falling water table caused by the uplift of the Atlasic system and probably by a change from wet tropical to monsoonal or semiarid climatic conditions.

The main chemical change during this stage resides in the complete release of sulfur from the pre-existent sulfides and the subsequent formation of $\mathrm{Pb}-\mathrm{Zn} \pm \mathrm{Cu}$ carbonates and sulfates as a result of the neutralizing effect of the Jurassic host carbonate rocks. The resulting mineral paragenesis occurs mainly as vein and fracture infills, and also as in situ replacement of primary sulfide ore minerals. The development of this lowtemperature paragenesis implies the complete oxidation of sulfide minerals, including oxidation of pyrite to oxyhydroxides, sphalerite to smithsonite-1, galena to anglesite- 1 and cerussite-1, and chalcopyrite to malachite and azurite. The oxidation involves mainly a series of reactions similar to those described by $[19,62,117-119]$ :

$\mathrm{PbS}+2 \mathrm{O}_{2} \rightarrow \mathrm{PbSO}_{4}$ under relatively low $\mathrm{pH}$ and high sulfate contents

$$
\begin{gathered}
\mathrm{PbSO}_{4}+\mathrm{H}_{2} \mathrm{CO}_{3} \rightarrow \mathrm{PbCO}_{3}+\mathrm{SO}_{4}{ }^{2-}+2 \mathrm{H}^{+} \text {, which is dependent on the activities of } \mathrm{H}^{+}, \\
\mathrm{H}_{2} \mathrm{CO}_{3}(\mathrm{aq}) \text {, and } \mathrm{SO}_{4}{ }^{2-} \\
\mathrm{PbS}+\mathrm{H}_{2} \mathrm{O}+\mathrm{CO}_{2}+2 \mathrm{O}_{2} \rightarrow \mathrm{PbCO}_{3}+\mathrm{H}_{2} \mathrm{SO}_{4}
\end{gathered}
$$

Smithsonite was generally produced during early oxidation of sphalerite, when Zn-bearing solutions reacted with the host carbonates or with carbonate-bearing fluids $[17,108,120]$ at $\mathrm{pH}$ values between 6.2 and 8.1 and under high partial pressures of $\mathrm{CO}_{2}\left(\mathrm{P}_{\mathrm{CO} 2(\mathrm{~g})}\right)$. Oxidation of galena occurred either as direct replacement of galena by anglesite, or as subsequent replacement of galena and anglesite by cerussite. The Pb-carbonate, 
which is widespread throughout most orebodies of the Touissit-Bou Beker district as void infills and replacement of the host dolostones (i.e., "cerusite pierreuse"), precipitated when solutions carrying carbonate reacted with galena, whereas anglesite formed in the presence of carbonate-poor fluids, as documented in other Moroccan supergene $\mathrm{Pb}-\mathrm{Zn} \pm$ $\mathrm{Cu}$ deposits [75]. Altogether, these observations indicate that during the main stage of sulfide oxidation, metals were quickly neutralized by the carbonate host rocks and did not migrate over long distances. The stronger evidence for short-distance migration of the metal-bearing fluids is provided by the occurrence of gypsum, whose precipitation in supergene environments is triggered by limited fluid migration [17].

Remarkably, the consistent increase of $\delta^{13} \mathrm{C}$ and $\delta^{18} \mathrm{O}$ values (Figure 9) along with the temporal shift from heavy (i.e., Gyp-1) to light sulfur (i.e., Gyp-2) sources with advancing paragenetic sequence could be explained in terms of microbial oxidation under decreasing $\mathrm{H}_{2} \mathrm{~S} / \mathrm{O}_{2}$ ratios and temperature conditions. This isotopic evolution could therefore reflect significant microbiologically sourced carbon input at relatively higher temperatures of formation during the paragenetically early sulfide oxidation stage as chemolithotrophs exothermically digested sulfides. Over time, as sulfide nutrients became scarcer in the oxidation zone, secondary carbonate minerals recorded progressively heavier $\delta^{13} \mathrm{C}$ and lighter $\delta^{34} \mathrm{~S}$ values at decreasing temperatures. This reflects the diminishing role of both microbes in the oxidation process, and the associated heat production from their digestion of sulfides, similar to processes documented in Australia [65]. Such evolution is also reflected in deposit mineralogy, as the resulting drop in $\mathrm{CO}_{2}$ partial pressures inhibited azurite formation at the expense of malachite, and as pseudomorph formation of malachite after azurite. In the final stages of oxidation, temperatures are near ambient, and $\delta^{13} \mathrm{C}$ values are dominated by dissolution of local carbonate rocks and atmospheric sources. In support of this conclusion, oxygen isotope thermometry from the coexisting azurite, malachite and late-stage calcite indicates decreasing temperatures from $34{ }^{\circ} \mathrm{C}$ to $19{ }^{\circ} \mathrm{C}$, assuming a local meteoric water $\delta^{18} \mathrm{O}$ value of $-7.2 \%$.

Overall, the calculated temperatures are similar to those determined for smithsonite, cerussite and azurite-malachite in other base metal supergene deposits worldwide (11$35{ }^{\circ} \mathrm{C}$, avg $20{ }^{\circ} \mathrm{C}$; $\left.[13,59,68,72]\right)$ and are in agreement with a continental environment in a temperate climate $[66,80]$. Although climatic variations and complex weathering histories could have produced the higher calculated temperatures that prevailed during the 'red calamine" stage, we suggest that the calculated higher temperatures of $32 \pm 3^{\circ} \mathrm{C}$ could reflect the heat produced by the exothermic oxidation of sulfides. If so, this indicates that oxidation of primary MVT ores could produce shallow subsurface temperatures up to $30{ }^{\circ} \mathrm{C}$ higher than local mean air temperatures [62].

Given the predominance of smithsonite over hemimorphite and the presence of silicarich mineral species such as willemite, we assume that the supergene weathering occurred under warm-dry climate conditions and low precipitation rates. In this regard, it is well documented that under humid-tropical climate, silica can be more efficiently leached from silicate rocks than $\mathrm{Al}$ or $\mathrm{Fe}[121,122]$. Moreover, the negative $\delta^{13} \mathrm{C}$ values, up to $-15 \%$ (Table 1 ), shown by smithsonite, suggest the involvement of a light component of carbon dominated by surface vegetation and/or secondary carbonate dissolution caused by a rising water table.

Thermochronological data [42-44,94-99] along with structural constraints indicate the involvement of a major pulse of exhumation (i.e., $\mathrm{D}_{3}$ of [42]) that occurred during the last $10 \mathrm{Ma}$, from middle/late Miocene to present, at an approximative shortening rate of $2.6 \mathrm{~mm} /$ year [44]. Additionally, geological correlations and comparison to similar supergene ore deposit types in the Mediterranean basin (e.g., [93]) and North Africa (e.g., [123]) indicate that the emplacement of the "red ore stage" could have occurred during the Pliocene-Pleistocene (8-7 Ma, [93]), coincident with an episode of sea-level rise in the study area at about $8 \mathrm{Ma}[28,124]$. Regionally, the authors of [123] show the occurrence of a main weathering event in Northern Tunisia during late Tortonian $(8.6 \pm 0.9$ 
Ma, (U-Th)/He on supergene goethite) and a later episode during late Pleistocene ( $0.8 \pm$ $0.2 \mathrm{Ma})$.

\subsection{Late Stage of Sulfide Oxidation: The "White Calamine" Ore Stage}

During this stage, the base metals released by the oxidation of sulfides were not trapped locally but transported by downward percolating meteoric fluids farther away from the sulfide protore, both vertically and laterally, and precipitated under more "oxidizing" conditions. The supergene fluids moved more than $150 \mathrm{~m}$ down dip and laterally through the Jurassic porous carbonate rocks and along the associated faulted corridors, where their acidity promoted further karstic dissolution. The dissolution was followed by partial to total replacement of the sulfide minerals by $\mathrm{Pb}-\mathrm{Zn} \pm \mathrm{Cu}$ carbonates and sulfates and, to a lesser extent, silicates. The resulting supergene mineral assemblages consist of various proportions of cerussite-2, anglesite-2, smithsonite-2, malachite-azurite-2, and, more importantly, hydrozincite as the most diagnostic phase that characterizes this stage. Gangue minerals include gypsum-2, calcite, and quartz.

The higher $\delta^{13} \mathrm{C}$ and $\delta^{18} \mathrm{O}$ values of the $\mathrm{Pb}-\mathrm{Zn} \pm \mathrm{Cu}$-bearing carbonates and sulfates from this stage, which reflect isotopic interaction at lower ambient temperatures between meteoric fluids and carbonate wall rocks, indicate carbonate and sulfate precipitation under more oxidizing conditions as the partial pressure of $\mathrm{CO}_{2(\mathrm{~g})}$ of the system reached equilibrium with the atmosphere and as $\mathrm{pH}$ increased from neutral to slightly alkaline values. The occurrence of hydrozincite constitutes further support that the supergene ore-bearing aqueous solutions were in equilibrium with the atmosphere (undersaturated zone) since hydrozincite is stable at $\mathrm{pCO}_{2(\mathrm{~g})}$ levels occurring in near-surface settings and thus lower than those allowing smithsonite precipitation (e.g., [108]). Higher aeration would have provided higher $\mathrm{O}_{2}$ concentration, allowing for a higher contribution of $\mathrm{O}_{2}$ during oxidation from air and producing carbonates and sulfates with higher $\delta^{13} \mathrm{C}$ and $\delta^{18} \mathrm{O}$ values. In addition to an atmospheric carbon source, the formation of hydrozincite should have benefited from the incorporation of an isotopically light component of carbon as a result of dissolved $\mathrm{CO}_{2}$ derived from the bacteria and archaea-mediated decay of organic matter (i.e., $\mathrm{C}_{3}-\mathrm{C}_{4}$ plants and soils) as discussed above. Paleoclimatic and/or seasonal variations, with lower $\delta^{18} \mathrm{O}$ values characterizing the winter season and higher $\delta^{18} \mathrm{O}$ values in summer, could also be invoked.

Given these relationships, hydrozincite precipitation must have occurred in relatively recent times, when the carbonate platform was already relatively uplifted. This observation suggests that the late stage of supergene oxidation occurred at higher altitudes, while the Atlas system continued to rise under the oblique convergence between Africa and Eurasia $[125,126]$. In this respect, structural and thermochronological data indicate relatively high exhumation rates of up to $0.3 \mathrm{~km} / \mathrm{Ma}$ from $5 \mathrm{Ma}$ to $0 \mathrm{Ma}$ (e.g [43,44]). If so, we document here a causal relationship between the fast exhumation rates and the timing of supergene mineralization in the Atlas system between $5 \mathrm{Ma}$ and $0 \mathrm{Ma}$, consistent with Ar-Ar dates (2-1 Ma to present; [93]) in the Mediterranean area and (U-Th)/He age determinations in Tunisia [123]. It is noteworthy that the amount of shortening of the Central High Atlas, which hosts the most productive calamine deposits in North Africa, is more than double compared to that of the Western High Atlas (approximately 30-34 km; [38,41,127]) and thus records higher exhumation rates. This observation could explain why the most significant supergene deposits are concentrated within the Central High Atlas and not elsewhere.

\section{Conclusions}

The present study constitutes the first integrated contribution that combines field observations with thorough mineralogical and geochemical investigations to constrain the origin(s) and evolution of the supergene fluid(s) and depositional processes that led to the precipitation of the non-sulfide mineralization in the Jurassic carbonate-hosted TouissitBou Beker and Jbel Bou Dahar Mississippi Valley-type districts. Economic supergene 
mineralization, which occurs as open-space fillings in intergranular voids, karsts, fractures, and breccias and as replacements of the host carbonates, consists of oxidized minerals resulting from weathering and alteration of hypogene sulfide mineralization. The secondary enrichment of the mineralized orebodies is assigned to both direct replacement and wall-rock replacement types. The resulting low-pressure, low-temperature non-sulfide ore assemblages consist predominantly of various proportions of smithsonite, hydrozincite, cerussite, anglesite, malachite, and azurite with subordinate amounts of willemite, pyromorphite, and sauconite. The main gangue minerals comprise calcite, aragonite, gypsum, and quartz. Three stages of supergene mineralization are recognized, the earliest of which constitutes a prerequisite for the development of the following two mineralized supergene stages. The first stage involves the oxidation of pyrite and subsequent development of gossanous manganese and iron hydroxide-rich blankets. The second stage of supergene mineralization, referred to as the main oxidation red calamine stage, accounts for significant amounts of the extracted non-sulfide ore and corresponds to the complete release of sulfur from the pre-existent sulfides and the subsequent formation of $\mathrm{Pb}-\mathrm{Zn} \pm \mathrm{Cu}$ carbonates and sulfates as a result of the neutralizing effect of the Jurassic host carbonates. The third post-oxidation stage, referred to as the late oxidation white calamine stage, is typified by the ultimate precipitation of hydrozincite.

Combined carbon, oxygen, and sulfur isotope compositions of ores are consistent with precipitation of the zinc and lead \pm copper non-sulfide mineralization in a supergene environment from in situ oxidation and replacement of the primary sulfide phases. The oxidation and replacement were due to meteoric fluids circulating in the carbonate rocks at ambient temperatures, which decreased with time from 32 to $18{ }^{\circ} \mathrm{C}$. More importantly, the layered stromatolitic-like textures, along with the light carbon and sulfur isotope compositions, reflect the involvement of a bacteriogenically mediated origin for the carbon and sulfur under temperate to warm climatic conditions. The released acidic fluids were channeled by the Jurassic permeable carbonates and by steep fracture and fault zones. The transport of dissolved metals out of the precursor sulfide bodies was facilitated by a falling water table caused by the tectonic uplift related to the Atlasic orogeny and a change from wet tropical to monsoonal or semiarid climatic conditions. The close spatial relationships between sulfide and non-sulfide ore zones and coexisting sulfide-non-sulfide mineral assemblages and geological settings along with stable isotope data suggest that the deposition of the supergene non-sulfide mineralization of the Moroccan Atlasic system may have occurred during the latest stages of uplift at $10 \mathrm{Ma}$, during intervals when the meteoric fluids were supplied by a relatively wet climate between the Late Miocene and Holocene. Periods of late Tortonian and late Pleistocene, recognized as weathering events in adjacent areas, are proposed as time spans for stages II and III of supergene mineralization. The process of oxidation may be ongoing today. Based on these findings, we recommend that for future regional to local-scale exploration campaigns for supergene lead-zinc \pm copper deposits, explorationists should combine all aspects of climatic evolution, long-wavelength neotectonics movements, and hydrogeology for a successful operation.

Author Contributions: Conceptualization, M.B.; methodology, M.B.; software, M.I.; validation, H.B., K.Z., and A.D.; formal analysis, E.M.; investigation, W.B.; resources, A.P. and J.Y.; data curation, W.B.; writing—original draft preparation, M.B.; writing—review and editing, G.L., J.Y.; visualization, J.P.; supervision, M.B.; project administration, M.B.; funding acquisition, J.Y. All authors have read and agreed to the published version of the manuscript.

Funding: This project received partial funding from the European Union's Learning mobility of individuals (Project Number BE01-KA107-016242) awarded to M.B. and J.Y.

Acknowledgments: We thank M. Ouadjou from Managemgroup company and A. Dinar from the CADETAF for sharing their statisics on the calamine production and for having granted access to their properties and subsequent surface exposure sampling. The two first authors are also greatly indebted to M. Boni and N. Mondillo for providing the Excel spreadsheet for calculation of the pre- 
cipitation temperatures of nonsulfide minerals. Reviews and edits by three anonymous Minerals referees are greatly appreciated.

Conflicts of Interest: The authors declare no conflict of interest.

\section{References}

1. Large, D. The Geology of Non-Sulfide Zinc Deposit-An Overview. Erzmetall 2001, 54, 264-276.

2. Boni, M.; Large, D. Nonsulfide Zinc Mineralization in Europe: An Overview. Econ. Geol. 2003, 98, 715-729. [CrossRef]

3. Hitzman, M.W.; Reynolds, N.A.; Sangster, D.F.; Allen, C.R.; Carman, C.E. Classification, genesis, and exploration guides for nonsulfide zinc deposits. Econ. Geol. 2003, 98, 685-714. [CrossRef]

4. Johnson, C.A.; Skinner, B.J. Geochemistry of the furnace magnetite bed, Franklin, New Jersey, and the relationship between stratiform iron oxide ores and stratiform zinc oxide-silicate ores in the New Jersey highlands. Econ. Geol. 2003, 98, 837-854. [CrossRef]

5. Bouabdellah, M.; Sangster, D.F.; Leach, D.L.; Brown, A.C.; Johnson, C.A.; Emsbo, P. Genesis of the Touissit-Bou Beker Mississippi valley-type district (Morocco-Algeria) and its relationship to the Africa-Europe collision. Econ. Geol. 2012, 107, 117-146. [CrossRef]

6. Mondillo, N.; Herrington, R.; Boyce, A.J.; Wilkinson, C.; Santoro, L.; Rumsey, M. Critical elements in non-sulfide Zn deposits: A reanalysis of the Kabwe Zn-Pb ores (central Zambia). Mineral. Mag. 2018, 82, S89-S114. [CrossRef]

7. Choulet, F.; Richard, J.; Boiron, M.-C.; Dekoninck, A.; Yans, J. Distribution of trace elements in willemite from the Belgium non-sulphide deposits. Eur. J. Mineral. 2019, 31, 983-997. [CrossRef]

8. Santoro, L.; Putzolu, F.; Mondillo, N.; Herrington, R.; Najorka, J.; Boni, M.; Dosbaba, M.; Maczurad, M.; Balassone, G. Quantitative mineralogical evaluation of Ni-Co laterite ores through XRPD-QPA- and automated SEM-based approaches: The Wingellina (Western Australia) case study. J. Geochem. Explor. 2021, 223, 106695. [CrossRef]

9. Melchiorre, E.B.; Enders, M.S. Stable Isotope Geochemistry of Copper Carbonates at the Northwest Extension Deposit, Morenci District, Arizona: Implications for Conditions of Supergene Oxidation and Related Mineralization. Econ. Geol. 2003, 98, 607-621. [CrossRef]

10. Höll, R.; Kling, M.; Schroll, E. Metallogenesis of germanium-A review. Ore Geol. Rev. 2007, 30, 145-180. [CrossRef]

11. Woollett, A. The processing of non-sulphide zinc deposits. In Proceedings of the Workshop on Nonsulfide Zn-Pb Deposits, Iglesias, Italy, 21-23 April 2005; Boni, M., Gilg, H.A., Eds.; European Science Foundation: Strasbourg, France, 2005.

12. De Wet, J.R.; Singleton, J.D. Development of a viable process for the recovery of zinc from oxide ores. J. S. Afr. Inst. Min. Metall. 2008, 108, 253-259.

13. Boni, M.; Mondillo, N. The "Calamines" and the "Others": The great family of supergene nonsulfide zinc ores. Ore Geol. Rev. 2015, 67, 208-233. [CrossRef]

14. Sangameshwar, S.R.; Barnes, H.L. Supergene process in zinc-lead-silver sulfide ores in carbonates. Econ. Geol. 1983, 78, 1379-1397. [CrossRef]

15. De Putter, T.; Ruffet, G. Supergene manganese ore records 75 Myr-long Campanian to Pleistocene geodynamic evolution and weathering history of the Central African Great Lakes Region-Tectonics drives, climate assists. Gondwana Res. 2020, 83, 96-117. [CrossRef]

16. Heyl, A.V.; Bozion, C.N. Oxidized zinc deposits of the United States, part I. General geology. Geol. Surv. Bull. 1962, 1135, 1-52.

17. Reichert, J.; Borg, G. Numerical simulation and a geochemical model of supergene carbonate-hosted non-sulphide zinc deposits. Ore Geol. Rev. 2008, 33, 134-151. [CrossRef]

18. Recheirt, J. Geochemical model of supergene carbonate-hosted nonsulphide zinc deposits. In Supergene Environments, Processes, and Products; Society of Economic Geologists: Littleton, CO, USA, 2009.

19. Paradis, S.; Simandl, G.J.; Keevil, H.; Raudsepp, M. Carbonate-hosted nonsulfide Pb-Zn deposits of the Quesnel Lake District, British Columbia, Canada. Econ. Geol. 2016, 111, 179-198. [CrossRef]

20. Southam, G.; Saunders, J.A. The geomicrobiology of ore deposits. Econ. Geol. 2005, 100, 1067-1084. [CrossRef]

21. Lengke, M.F.; Southam, G. The deposition of elemental gold from gold(I)-thiosulfate complexes mediated by sulfate-reducing bacterial conditions. Econ. Geol. 2007, 102, 109-126. [CrossRef]

22. Kucha, H.; Schroll, E.; Raith, J.G.; Halas, S. Microbial sphalerite formation in carbonate-hosted Zn-Pb ores, Bleiberg, Austria: Micro- to nanotextural and sulfur isotope evidence. Econ. Geol. 2010, 105, 1005-1023. [CrossRef]

23. Tornos, F.; Velasco, F.; Menor-Salván, C.; Delgado, A.; Slack, J.F.; Escobar, J.M. Formation of recent Pb-Ag-Au mineralization by potential sub-surface microbial activity. Nat. Commun. 2014, 5, 4800. [CrossRef] [PubMed]

24. Tisato, N.; Torriani, S.F.F.; Monteux, S.; Sauro, F.; De Waele, J.; Tavagna, M.L.; D'Angeli, I.M.; Chailloux, D.; Renda, M.; Eglinton, T.I.; et al. Microbial mediation of complex subterranean mineral structures. Sci. Rep. 2015, 5, 15525. [CrossRef] [PubMed]

25. Little, C.T.S.; Johannessen, K.C.; Bengtson, S.; Chan, C.S.; Ivarsson, M.; Slack, J.F.; Broman, C.; Thorseth, I.H.; Grenne, T.; Rouxel, O.J.; et al. A late Paleoproterozoic (1.74 Ga) deep-sea, low-temperature, iron-oxidizing microbial hydrothermal vent community from Arizona, USA. Geobiology 2021. [CrossRef] [PubMed]

26. Bouabdellah, M.; Sangster, D.F. Geology, Geochemistry, and Current Genetic Models for Major Mississippi Valley-Type Pb-Zn Deposits of Morocco. In Mineral Deposits of North Africa; Bouabdellah, M., Slack, J.F., Eds.; Springer International Publishing: Cham, Switzerland, 2016; pp. 463-495. 
27. Adil, S.; Bouabdellah, M.; Grandia, F.; Cardellach, E.; Canals, À. Caractérisation géochimique des fluides associés aux minéralisations Pb-Zn de Bou-Dahar (Maroc). C. R. Geosci. 2004, 336, 1265-1272. [CrossRef]

28. Bouabdellah, M.; Niedermann, S.; Velasco, F. The Touissit-Bou Beker Mississippi Valley-type district of northeastern Morocco: Relationships to the Messinian salinity crisis, late Neogene-Quaternary alkaline magmatism, and buoyancy-driven fluid convection. Econ. Geol. 2015, 110, 1455-1484. [CrossRef]

29. Rddad, L.; Bouhlel, S. The Bou Dahar Jurassic carbonate-hosted Pb-Zn-Ba deposits (Oriental High Atlas, Morocco): Fluid-inclusion and C-O-S-Pb isotope studies. Ore Geol. Rev. 2016, 72, 1072-1087. [CrossRef]

30. Choulet, F.; Charles, N.; Barbanson, L.; Branquet, Y.; Sizaret, S.; Ennaciri, A.; Badra, L.; Chen, Y. Non-sulfide zinc deposits of the moroccan high atlas: Multi-scale characterization and origin. Ore Geol. Rev. 2014, 56, 115-140. [CrossRef]

31. Choulet, F.; Barbanson, L.; Buatier, M.; Richard, J.; Vennemann, T.; Ennaciri, A.; Zouhair, M. Characterization and origin of low-T willemite (Zn2SiO4) mineralization: The case of the Bou Arhous deposit (High Atlas, Morocco). Miner. Depos. 2017, 52, 1085-1102. [CrossRef]

32. Choulet, F.; Buatier, M.; Barbanson, L.; Guégan, R.; Ennaciri, A. Zinc-rich clays in supergene non-sulfide zinc deposits. Miner. Depos. 2016, 51, 467-490. [CrossRef]

33. Rajlich, P. Geology of Oued Mekta, a Mississippi Valley-type deposit, Touissit-Bou Beker region, eastern Morocco. Econ. Geol. 1983, 78, 1239-1254. [CrossRef]

34. Dupuy, J.-J.; Touray, J.-C. Multistage ore deposition at the Oued Mekta strata-bound lead deposit, Touissit-Bou Beker District, eastern Morocco. Econ. Geol. 1986, 81, 1558-1561. [CrossRef]

35. Makhoukhi-Marrakchi, S. Le Gisement de Plomb de Beddiane (Maroc Oriental): Gitologie et Élément de Modélisation d'une Mineralisation de Type Mississipi Valley. Ph.D. Thesis, École Normale Supérieure, Paris, France, 1993.

36. Bouabdellah, M.; Brown, A.C.; Héroux, Y. Pétrographie et altération de la matière organiquedu gisement de plomb-zinc-cuivre de tourist-Bou Beker, Maroc nord oriental. Can. J. Earth Sci. 1996, 33, 1363-1374. [CrossRef]

37. Laville, E.; Pique, A. La Distension crustale atlantique et atlasique au Maroc au debut du Mesozoique; le rejeu des structures hercyniennes. Bull. Soc. Géol. Fr. 1991, 162, 1161-1171.

38. Beauchamp, W.; Allmendinger, R.W.; Barazangi, M.; Demnati, A.; El Alji, M.; Dahmani, M. Inversion tectonics and the evolution of the High Atlas Mountains, Morocco, based on a geological geophysical transect. Tectonics 1999, 18, 163-184. [CrossRef]

39. Beauchamp, W.; Barazangi, M.; Demnati, A.; El Alji, M. Intracontinental rifting and inversion: Missour basin and Atlas mountains, Morocco. Am. Assoc. Pet. Geol. Bull. 1996, 80, 1459-1482.

40. Teixell, A.; Barnolas, A.; Rosales, I.; Arboleya, M.L. Structural and facies architecture of a diapir-related carbonate minibasin (lower and middle Jurassic, High Atlas, Morocco). Mar. Pet. Geol. 2017, 81, 334-360. [CrossRef]

41. Teixell, A.; Arboleya, M.-L.; Julivert, M.; Charroud, M. Tectonic shortening and topography in the central High Atlas (Morocco). Tectonics 2003, 22, 1051. [CrossRef]

42. Leprêtre, R.; Missenard, Y.; Barbarand, J.; Gautheron, C.; Jouvie, I.; Saddiqi, O. Polyphased Inversions of an Intracontinental Rift: Case Study of the Marrakech High Atlas, Morocco. Tectonics 2018, 37, 818-841. [CrossRef]

43. Lanari, R.; Fellin, M.G.; Faccenna, C.; Balestrieri, M.L.; Pazzaglia, F.J.; Youbi, N.; Maden, C. Exhumation and Surface Evolution of the Western High Atlas and Surrounding Regions as Constrained by Low-Temperature Thermochronology. Tectonics 2020, 39. [CrossRef]

44. Lanari, R.; Faccenna, C.; Fellin, M.G.; Essaifi, A.; Nahid, A.; Medina, F.; Youbi, N. Tectonic Evolution of the Western High Atlas of Morocco: Oblique Convergence, Reactivation, and Transpression. Tectonics 2020, 39. [CrossRef]

45. Voirin, J. Géologie du gisement plombo-zincifère de Bou Beker. Colloque sur les gîtes stratiformes de plomb, zinc et manganèse du Maroc 1962. Notes Mém. Serv. Géol. Maroc 1965, 181, 21-68.

46. Jébrak, M.; Marcoux, É.; Nasloubi, M.; Zaharaoui, M. From sandstone- to carbonate-hosted strata bound deposits: An isotope study of galena in the Upper-Moulouya District (Morocco). Miner. Depos. 1998, 33, 406-415. [CrossRef]

47. Torbi, A.; Gélard, J.P. Paléocontraintes enregistrées par la microfracturation, depuis l'Hercynien jusqu'à l'Actuel, dans les Monts du Sud-Est d'Oujda (Meseta orientale, Maroc). C. R. Acad. Sci. Paris 1994, 318, 131-135.

48. Bouhlel, S.; Leach, D.L.; Johnson, C.A.; Marsh, E.; Salmi-Laouar, S.; Banks, D.A. A salt diapir-related Mississippi Valley-type deposit: The Bou Jaber Pb-Zn-Ba-F deposit, Tunisia: Fluid inclusion and isotope study. Miner. Depos. 2016, 51, 749-780. [CrossRef]

49. Samson, P. Un gisement plombo-zincifère en milieu récifal: Touissit (Maroc oriental). Notes Mém. Ser. Géol. Maroc 1973, 242, 1-133.

50. Owodenko, B. Le Bassin Houiller de Jérada (Maroc Oriental): Essai de synthèse et de paléogéographie. Notes Mém. Ser. Géol. Maroc 1976, 207, 1-147.

51. Valin, F.; Rakus, M. Rapport concernant l'étude géologique du Paléozoique et de la couverture mésozoique dans les Monts d'Oujda. Unpubl. Rep. Serv. Géol. Oujda 1979, 60, 73.

52. Verati, C.; Rapaille, C.; Féraud, G.; Marzoli, A.; Bertrand, H.; Youbi, N. 40Ar/39Ar ages and duration of the Central Atlantic Magmatic Province volcanism in Morocco and Portugal and its relation to the Triassic-Jurassic boundary. Palaeogeogr. Palaeoclimatol. Palaeoecol. 2007, 244, 308-325. [CrossRef]

53. Crevello, P.D. Stratigraphic Evolution of Lower Jurassic Carbonate Platforms: Record of Rift Tectonics and Eustatsy, Central and Eastern High Atlas, Morocco. Ph.D. Thesis, Colorado School of Mines, Golden, CO, USA, 1990.

54. Blomeier, D.P.; Reijmer, J.J. Drowning of a Lower Jurassic carbonate platform: Jbel Bou Dahar, High Atlas, Morocco. Facies 1999, 4 , 81-110. [CrossRef] 
55. Campbell, A.E.; Stafleu, J. Seismic modeling of an Early Jurassic, drowned carbonate platform: Djebel Bou Dahar, High Atlas, Morocco. AAPG Bull. 1992, 76, 1760-1777.

56. Dresnay, D.R. Sédiments jurassiques du domaine des chaînes atlasiques du Maroc. Symposium “Sédimentation jurassique W européenne.". ASF Publ. Spec. 1979, 1, 345-365.

57. Agard, J.; Dresnay, D.R. Les gîtes plombo-zincifères du Jbel Bou Dahar près de Beni-Tajjite (Haut Atlas oriental). Notes Mém. Ser. Géol. Maroc. 1965, 181, 135-166.

58. Coplen, T.B. Discontinuance of SMOW and PDB. Nature 1995, 375, 285. [CrossRef]

59. Gilg, H.A.; Boni, M.; Hochleitner, R.; Struck, U. Stable isotope geochemistry of carbonate minerals in supergene oxidation zones of $\mathrm{Zn}-\mathrm{Pb}$ deposits. Ore Geol. Rev. 2008, 33, 117-133. [CrossRef]

60. Füger, A.; Méheut, M.; Mavromatis, V.; Leis, A.; Dietzel, M. Oxygen isotope fractionation during smithsonite formation from aqueous solutions. Chem. Geol. 2018, 495, 76-89. [CrossRef]

61. Melchiorre, E.B.; Criss, R.E.; Rose, T.P. Oxygen and carbon isotope study of natural and synthetic malachite. Econ. Geol. 1999, 94, 245-259. [CrossRef]

62. Melchiorre, E.B.; Criss, R.E.; Rose, T.P. Oxygen and Carbon Isotope Study of Natural and Synthetic Azurite. Econ. Geol. 2000, 95, 621-628. [CrossRef]

63. O'Neil, J.R.; Clayton, R.N.; Mayeda, T.K. Oxygen isotope fractionation in divalent metal carbonates. J. Chem. Phys. 1969, 51, 5547-5558. [CrossRef]

64. Melchiorre, E.B.; McLaughlin, D.; Bottrill, R.; Hight, J. Primary diagenetic copper carbonate at the Malbunka copper deposit, Amadeus Basin, Northern Territory, Australia. Ore Geol. Rev. 2017, 82, 170-180. [CrossRef]

65. Melchiorre, E.B.; Williams, P.A. Stable Isotope Characterization of the Thermal Profile and Subsurface Biological Activity during Oxidation of the Great Australia Deposit, Cloncurry, Queensland, Australia. Econ. Geol. 2001, 96, 1685-1693. [CrossRef]

66. Navarro-Ciurana, D.; Campos-Quispe, L.A.; Cardellach, E.; Vindel, E.; Gómez-Gras, D.; Griera, A.; Corbella, M. Mineralogical and geochemical characterization of the Riópar non-sulfide Zn-(Fe-Pb) deposits (Prebetic Zone, SE Spain). Ore Geol. Rev. 2016, 79, 515-532. [CrossRef]

67. Mondillo, N.; Lupone, F.; Boni, M.; Joachimski, M.; Balassone, G.; De Angelis, M.; Zanin, S.; Granitzio, F. From Alpine-type sulfides to nonsulfides in the Gorno Zn project (Bergamo, Italy). Miner. Depos. 2020, 55, 953-970. [CrossRef]

68. Boni, M.; Gilg, H.A.; Aversa, G.; Balassone, G. The "Calamine" of Southwest Sardinia: Geology, Mineralogy, and Stable Isotope Geochemistry of Supergene Zn Mineralization. Econ. Geol. 2003, 98, 731-748. [CrossRef]

69. Veizer, J.; Ala, D.; Azmy, K.; Bruckschen, P.; Buhl, D.; Bruhn, F.; Garden, G.A.F.; Diener, A.; Ebneth, S.; Godderis, Y.; et al. ${ }^{87}$ Sr $/{ }^{86}$ Sr, $\delta^{13} \mathrm{C}$ and $\delta^{18} \mathrm{O}$ evolution of Phanerozoic seawater. Chem. Geol. 1999, 161, 59-88. [CrossRef]

70. Jenkyns, H.C.; Jones, C.E.; Gröcke, D.R.; Hesselbo, S.P.; Parkinson, D.N. Chemostratigraphy of the Jurassic System: Applications, limitations and implications for palaeoceanography. J. Geol. Soc. Lond. 2002, 159, 351-378. [CrossRef]

71. Choquette, P.W.; James, N.P. DIAGENESIS \#12. Diagenesis in Limestones-3. The Deep Burial Environment. Geosci. Can. 1987, 14, 3-35.

72. Garnit, H.; Boni, M.; Buongiovanni, G.; Arfè, G.; Mondillo, N.; Joachimski, M.; Bouhlel, S.; Balassone, G. C-O stable isotopes geochemistry of Tunisian nonsulfide zinc deposits: A first look. Minerals 2018, 8, 13. [CrossRef]

73. Claypool, G.E.; Holser, W.T.; Kaplan, I.R.; Sakai, H.; Zak, I. The age curves of sulfur and oxygen isotopes in marine sulfate and their mutual interpretation. Chem. Geol. 1980, 28, 199-260. [CrossRef]

74. Kampschulte, A.; Strauss, H. The sulfur isotopic evolution of Phanerozoic seawater based on the analysis of structurally substituted sulfate in carbonates. Chem. Geol. 2004, 204, 255-286. [CrossRef]

75. Verhaert, M.; Bernard, A.; Dekoninck, A.; Lafforgue, L.; Saddiqi, O.; Yans, J. Mineralogical and geochemical characterization of supergene $\mathrm{Cu}-\mathrm{Pb}-\mathrm{Zn}-\mathrm{V}$ ores in the oriental High Atlas, Morocco. Miner. Depos. 2017, 52, 1049-1068. [CrossRef]

76. Poot, J.; Verhaert, M.; Dekoninck, A.; Oummouch, A.; Basbas, A.E.; Maacha, L.; Yans, J. Characterization of weathering processes of the giant copper deposit of tizert (Igherm inlier, anti-atlas, Morocco). Minerals 2020, 10, 620. [CrossRef]

77. Fontaine, L.; De Putter, T.; Bernard, A.; Decrée, S.; Cailteux, J.; Wouters, J.; Yans, J. Complex mineralogical-geochemical sequences and weathering events in the supergene ore of the $\mathrm{Cu}$-Co Luiswishi deposit (Katanga, D.R. Congo). J. Afr. Earth Sci. 2020, 161, 103674. [CrossRef]

78. Barbarand, J.; Bour, I.; Pagel, M.; Quesnel, F.; Delcambre, B.; Dupuis, C.; Yans, J. Post-Paleozoic evolution of the northern Ardenne Massif constrained by apatite fission-track thermochronology and geological data. BSGF Earth Sci. Bull. 2018, 189, 16. [CrossRef]

79. Ouda, B.; El Hamdaoui, A.; Ibn Majah, M. Isotopic Composition of Precipitation in the Mediterranean Basin in Relation to Air Circulation Patterns and Climate; IAEA TECDOC 1453; International Atomic Energy Agency: Vienna, Austria, 2005; pp. $125-140$.

80. Tassi, F.; Vaselli, O.; Moratti, G.; Piccardi, L.; Minissale, A.; Poreda, A.; Huertas, A.D.; Bendkik, A.; Chenakeb, M.; Tedesco, D. Fluid geochemistry versus tectonic setting: The case study of Morocco. In Tectonics of the Western Mediterranean and North Africa; Moratti, G., Chalouan, A., Eds.; Geological Society of London: London, UK, 2006; Volume 262, pp. 131-145.

81. Bouchaou, L.; Warner, N.R.; Tagma, T.; Hssaisoune, M.; Vengosh, A. The origin of geothermal waters in Morocco: Multiple isotope tracers for delineating sources of water-rock interactions. Appl. Geochem. 2017, 84, 244-253. [CrossRef]

82. Coppola, V.; Boni, M.; Gilg, A.H.; Strzelska-Smakowska, B. Nonsulfide zinc deposits in the Silesia-Cracow district, Southern Poland. Miner. Depos. 2009, 44, 559-580. [CrossRef]

83. Criss, R.E. Principles of Stable Isotope Distribution; Oxford University Press: Oxford, UK, 1999; p. 254. 
84. Deines, P. The carbon isotopic composition of diamonds: Relationship to diamond shape, color, occurrence and vapor composition. Geochim. Cosmochim. Acta 1980, 44, 943-961. [CrossRef]

85. Cerling, T.E.; Quade, J. Stable Carbon and Oxygen Isotopes in Soil Carbonates. In Climate Change in Continental Isotopic Records; American Geophysical Union (AGU): Washington, DC, USA, 1993; pp. 217-231.

86. Schmitt, H. Equilibrium Diagrams for Minerals at Low Temperature and Pressure; Harvard University: Cambridge, MA, USA, 1962; p. 23.

87. Garrels, R.M.; Christ, C. Solutions, Minerals, and Equilibria; Harper and Row: New York, NY, USA, $1965 ;$ p. 450.

88. Williams, P.A. Oxide Zone Geochemistry; Ellis Horwood Limited: Chichester, UK, 1990; p. 286.

89. Enders, M.S.; Knickerbocker, C.; Southam, G.; Titley, S.R. The occurrence of acidophilic iron oxidizing bacteria and their role in supergene enrichment of the Morenci porphyry copper deposit, Greenlee County, Arizona [abs]. In Proceedings of the Geological Society of America, Abstracts with Programs; Geological Society of America: Bolder, CO, USA, 1998; Volume 30 , p. A205.

90. Zerkle, A.L.; Farquhar, J.; Johnston, D.T.; Cox, R.P.; Canfield, D.E. Fractionation of multiple sulfur isotopes during phototrophic oxidation of sulfide and elemental sulfur by a green sulfur bacterium. Geochim. Cosmochim. Acta 2009, 73, 291-306. [CrossRef]

91. Dravis, J.J. Hardened subtidal stromatolites, Bahamas. Science 1983, 219, 385-386. [CrossRef]

92. Podda, F.; Zuddas, P.; Minacci, A.; Pepi, M.; Baldi, F. Heavy metal coprecipitation with hydrozincite [Zn5 (CO3) 2 (OH) 6$]$ from mine waters caused by photosynthetic microorganisms. Appl. Environ. Microbiol. 2000, 66, 5092-5098. [CrossRef]

93. De Giudici, G.; Podda, F.; Sanna, R.; Musu, E.; Tombolini, R.; Cannas, C.; Musinu, A.; Casu, M. Structural properties of biologically controlled hydrozincite: An HRTEM and NMR spectroscopic study. Am. Mineral. 2009, 94, 1698-1706. [CrossRef]

94. Ngwenya, B.T.; Magennis, M.; Podda, F.; Gromov, A. Self-preservation strategies during bacterial biomineralization with reference to hydrozincite and implications for fossilization of bacteria. J. R. Soc. Interface 2014, 11, 20140845. [CrossRef]

95. Velasco, F.; Herrero, J.M.; Suárez, S.; Yusta, I.; Alvaro, A.; Tornos, F. Supergene features and evolution of gossans capping massive sulphide deposits in the Iberian Pyrite Belt. Ore Geol. Rev. 2013, 53, 181-203. [CrossRef]

96. Barbero, L.; Teixell, A.; Arboleya, M.L.; del Río, P.; Reiners, P.W.; Bougadir, B. Jurassic-to-present thermal history of the central High Atlas (Morocco) assessed by low-temperature thermochronology. Terra Nova 2007, 19, 58-64. [CrossRef]

97. Missenard, Y.; Saddiqi, O.; Barbarand, J.; Leturmy, P.; Ruiz, G.; El Haimer, F.Z.; de Lamotte, D.F. Cenozoic denudation in the Marrakech High Atlas, Morocco: Insight from apatite fission-track thermochronology. Terra Nova 2008, 20, 221-228. [CrossRef]

98. Balestrieri, M.L.; Moratti, G.; Bigazzi, G.; Algouti, A. Neogene exhumation of the Marrakech High Atlas (Morocco) recorded by apatite fission-track analysis. Terra Nova 2009, 21, 75-82. [CrossRef]

99. Ghorbal, B. Mesozoic to Quaternary Thermo-Tectonic Evolution of Morocco (NW Africa): An Integrated Study of the High Atlas Orogen and Adjacent Regions Assessed From Low-Temperature Geochronology. Ph.D. Thesis, Vrije University, Amsterdam, The Netherlands, 2009.

100. Domènech, M. Rift Opening and Inversion in the Marrakech High Atlas: Integrated Structural and Thermochronologic Study. Ph.D. Thesis, Universitat Autonoma de Barcelona, Barcelona, Spain, 2015.

101. Domènech, M.; Teixell, A.; Stockli, D.F. Magnitude of rift-related burial and orogenic contraction in the Marrakech High Atlas revealed by zircon (U-Th)/He thermochronology and thermal modeling. Tectonics 2016, 35, 2609-2635. [CrossRef]

102. Maley, J. Les changements climatiques de la fin du Tertiaire en Afrique: Leurs conséquences sur l'apparition du Sahara et de sa végétation. In The Sahara and the Nile; Williams, A.J., Faure, H., Eds.; Balkema: Rotterdam, The Netherlands, 1980 ; pp. 63-86.

103. Le Houérou, H.N. Climate, flora and fauna changes in the sahara over the past 500 million years. J. Arid Environ. 1997, 37, 619-647. [CrossRef]

104. Cheddadi, R.; Lamb, H.F.; Guiot, J.; van der Kaars, S. Holocene climatic change in Morocco: A quantitative reconstruction from pollen data. Clim. Dyn. 1998, 14, 883-890. [CrossRef]

105. Rognon, P. Late quaternary climatic reconstruction for the maghreb (North Africa). Palaeogeogr. Palaeoclimatol. Palaeoecol. 1987, 58, 11-34. [CrossRef]

106. Leach, D.L.; Bradley, D.C.; Huston, D.; Pisarevsky, S.A.; Taylor, R.D.; Gardoll, S.J. Sediment-Hosted Lead-Zinc Deposits in Earth History. Econ. Geol. 2010, 105, 593-625. [CrossRef]

107. Leach, D.L.; Taylor, R.D.; Fey, D.L.; Diehl, S.F.; Saltus, R.W. A deposit model for Mississippi Valley-type lead-zinc ores. Dans Mineral deposit models for resource assessment. In Critical Reviews of Oxidative Stress and Aging; Cutler, R.G., Boucher, D., Eds.; World Scientific Publishing Co. Pte. Ltd: Singapore, 2010; pp. 48-64. [CrossRef]

108. Takahashi, T. Supergene alteration of zinc and lead deposits in limestone. Econ. Geol. 1960, 55, 1083-1115. [CrossRef]

109. McPhail, D.C.; Summerhayes, E.; Welch, S.; Brugger, J. The geochemistry and mobility of zinc in the regolith. In Advances in Regolith; Roach, I.C., Ed.; Cooperative Research Centre for Landscape Environments and Mineral Exploration: Millaa Millaa, QLD, Australia, 2003; pp. 287-291.

110. Leprêtre, R.; Missenard, Y.; Barbarand, J.; Gautheron, C.; Saddiqi, O.; Pinna-Jamme, R. Postrift history of the eastern central Atlantic passive margin: Insights from the Saharan region of South Morocco: Postrift Evolution Moroccan Margin. J. Geophys. Res. Solid Earth 2015, 120, 4645-4666. [CrossRef]

111. Verhaert, M.; Bernard, A.; Saddiqi, O.; Dekoninck, A.; Essalhi, M.; Yans, J. Mineralogy and genesis of the polymetallic and polyphased low grade Fe-Mn-Cu ore of Jbel Rhals deposit (Eastern High Atlas, Morocco). Minerals 2018, 8, 39. [CrossRef]

112. Dekoninck, A.; Ruffet, G.; Missenard, Y.; Parizot, O.; Magoua, M.; Mouttaqi, A.; Rochez, G.; Yans, J. Multistage genesis of the late Cretaceous manganese karst-hosted Tasdremt deposit (High Atlas, Morocco). Miner. Depos. 2020, 1-22. [CrossRef] 
113. Bladh, K.W. The formation of goethite, jarosite, and alunite during the weathering of sulfide-bearing felsic rocks. Econ. Geol. 1982, 77, 176-184. [CrossRef]

114. Boyle, D.R. Oxidation of massive sulfide deposits in the Bathurst mining camp, New Brunswick: Natural analogues for acid drainage in temperate climates In Environmental Geochemistry of Sulfide Oxidation; ACS Publications: Washington, DC, USA, $1994 ;$ pp. 534-550.

115. Lafforgue, L.; Dekoninck, A.; Barbarand, J.; Brigaud, B.; Bouabdellah, M.; Verhaert, M.; Mouttaqi, A.; Yans, J. Geological and geochemical constrains on the genesis of the sedimentary-hosted Bou Arfa Mn(-Fe) deposit (Eastern High Atlas, Morocco). Ore Geol. Rev. 2021, 133, 104094. [CrossRef]

116. Jurjovec, J.; Ptacek, C.J.; Blowes, D.W. Acid neutralization mechanisms and metal release in mine tailings: A laboratory column experiment. Geochim. Cosmochim. Acta 2002, 66, 1511-1523. [CrossRef]

117. Nordstrom, D.K. The effect of sulfate on aluminum concentrations in natural waters: Some stability relations in the system Al2O3-SO3-H2O at 298 K. Geochim. Cosmochim. Acta 1982, 46, 681-692. [CrossRef]

118. Nordstrom, D.K.; Alpers, C.N. The geochemistry of acid mine waters. In The Environmental Geochemistry of Mineral Deposits: Part A: Processes, Methods and Health Issues; Plumlee, G.S., Logsdon, M.J., Eds.; Society of Economic Geologists: Littleton, CO, USA, 1999; pp. 133-160.

119. Nordstrom, D.K.; Alpers, C.N. Negative pH, efflorescent mineralogy, and consequences for environment restoration at the Iron Mountain Superfund site, California. Proc. Natl. Acad. Sci. USA 1999, 96, 3455-3462. [CrossRef]

120. Reichert, J. A geochemical model of supergene carbonate-hosted nonsulfide zinc deposits. Soc. Econ. Geol. Spec. Publ. 2009, 14, 69-76.

121. White, A.F.; Blum, A.E. Effects of climate on chemical-weathering in watersheds. Geochim. Cosmochim. Acta 1995, 59, 1729-1747. [CrossRef]

122. Retallack, G.J. Lateritization and Bauxitization Events. Econ. Geol. 2010, 105, 655-667. [CrossRef]

123. Yans, J.; Verhaert, M.; Gautheron, C.; Antoine, P.-O.; Moussi, B.; Dekoninck, A.; Decrée, S.; Chaftar, H.-R.; Hatira, N.; Dupuis, C.; et al. (U-Th)/He Dating of Supergene Iron (Oxyhydr-)Oxides of the Nefza-Sejnane District (Tunisia): New Insights into Mineralization and Mammalian Biostratigraphy. Minerals 2021, 11, 260. [CrossRef]

124. Bouabdellah, M.; Castorina, F.; Bodnar, R.J.; Banks, D.; Jébrak, M.; Prochaska, W.; Lowry, D.; Klügel, A.; Hoernle, K. Petroleum Migration, Fluid Mixing, and Halokinesis as the Main Ore-Forming Processes at the Peridiapiric Jbel Tirremi Fluorite-Barite Hydrothermal Deposit, Northeastern Morocco. Econ. Geol. 2014, 109, 1223-1256. [CrossRef]

125. Dewey, J.F.; Helman, M.L.; Knott, S.D.; Turco, E.; Hutton, D.H.W. Kinematics of the western Mediterranean. Geol. Soc. Lond. Spec. Publ. 1989, 45, 265-283. [CrossRef]

126. Serpelloni, E.; Vannucci, G.; Pondrelli, S.; Argnani, A.; Casula, G.; Anzidei, M.; Baldi, P.; Gasperini, P. Kinematics of the Western Africa-Eurasia plate boundary from focal mechanisms and GPS data. Geophys. J. Int. 2007, 169, 1180-1200. [CrossRef]

127. Gomez, F.; Beauchamp, W.; Barazangi, M. Role of the Atlas Mountains (northwest Africa) within the African-Eurasian plateboundary zone. Geology 2000, 28, 775-778. [CrossRef] 